
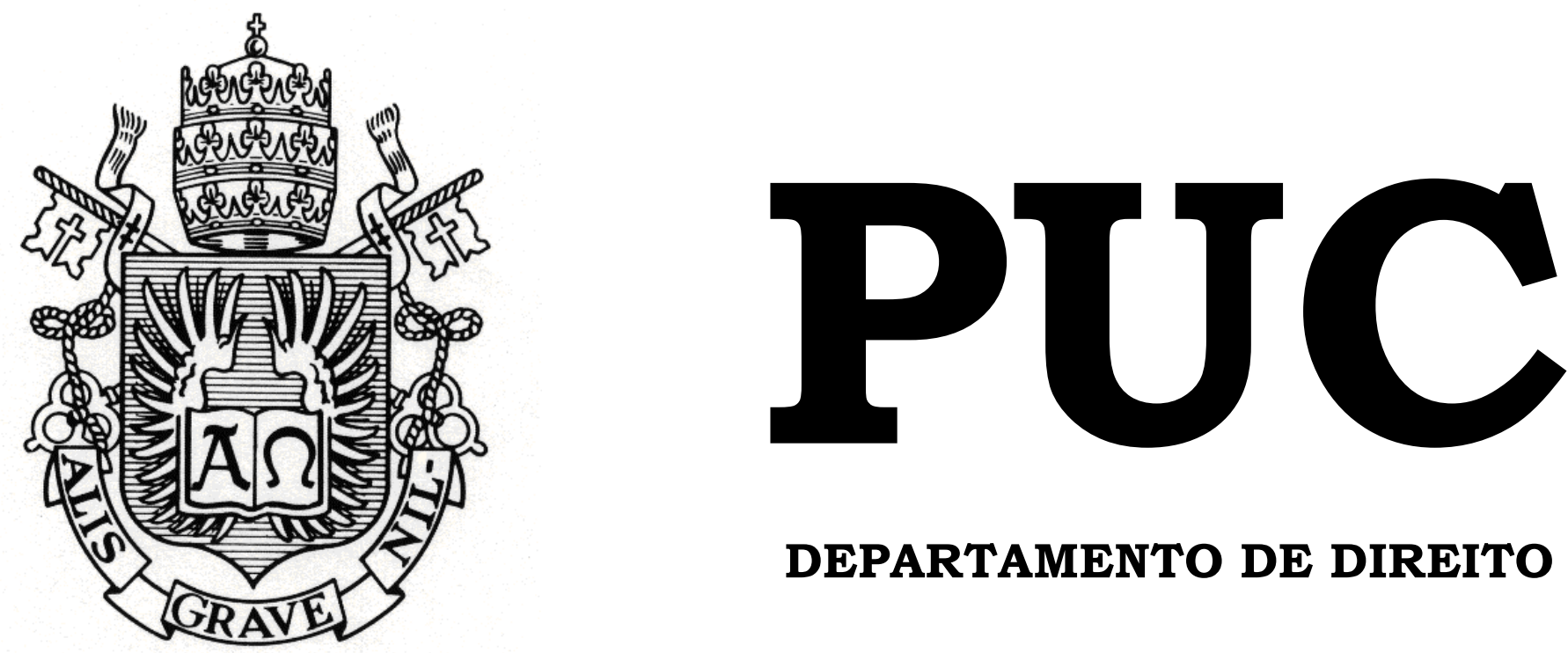

DEPARTAMENTO DE DIREITO

\title{
A MOROSIDADE DA ADMINISTRAÇÃO PÚBLICA NO RECONHECIMENTO DO DIREITO À PROTEÇÃO PATENTÁRIA: UMA ANÁLISE CONSTITUCIONAL
}

por

Gabriela Assumpção Pinheiro Machado

ORIENTADORA: Regina Coeli Lisboa Soares 2018.1

PONTIFÍCIA UNIVERSIDADE CATÓLICA DO RIO DE JANEIRO RUA MARQUÊS DE SÃO VICENTE, 225 - CEP 22453-900 


\title{
A MOROSIDADE DA ADMINISTRAÇÃO PÚBLICA NO RECONHECIMENTO DO DIREITO À PROTEÇÃO PATENTÁRIA: UMA ANÁLISE CONSTITUCIONAL
}

\author{
por \\ Gabriela Assumpção Pinheiro Machado
}

Monografia

apresentada

ao

Departamento de Direito da Pontifícia Universidade Católica do Rio de Janeiro (PUC-Rio) para a obtenção do Título de Bacharel em Direito.

Orientadora: Regina Coeli Lisboa Soares 


\section{Agradecimentos}

Gostaria de agradecer, primeiramente, aos meus pais, Denise e Pedro, por me proporcionarem tantas oportunidades e terem me guiado até esse momento.

Ao meu irmão, Tiago, por todo o carinho e cuidado.

Ao meu namorado, Gabriel, por toda a paciência enquanto escrevi este trabalho, companheirismo e amor.

Aos amigos que fiz durante a faculdade, em especial à Luisa Penna e Giovanna Ortiz, pela parceria e tantos bons momentos juntas.

Aos meus amigos e colegas do escritório, por todo o aprendizado e convivência diária.

Por fim, gostaria de agradecer imensamente à minha orientadora, Regina, pelo incentivo para abordar este tema e por todos os ensinamentos, não só durante este trabalho, mas também nos dois períodos da faculdade em que tive o prazer de ser sua aluna. 


\section{Resumo}

O presente trabalho aborda o problema da morosidade na análise dos pedidos de patente sob a ótica dos princípios constitucionais que regem a atuação da Administração Pública, em especial os princípios da eficiência, duração razoável do processo administrativo e segurança jurídica. Para tal busca esclarecer, em um primeiro momento, o papel desses princípios no exercício das atividades da Administração Pública, tal como o exame dos pedidos de patente. Posteriormente, aborda as características e objetivos do sistema patentário brasileiro e do processo administrativo de concessão de patentes, a fim de tornar claro o objeto de análise do presente trabalho. Ao final, se debruça sobre os dados disponibilizados pelo INPI acerca da morosidade no procedimento administrativo de exame dos pedidos de patente para, enfim, analisar o problema da morosidade da Administração Pública no reconhecimento do direito à proteção patentária à luz dos mencionados princípios constitucionais. Dessa forma, pretende revelar a importância da observância desses princípios pela Administração Pública para que os objetivos do sistema patentário brasileiro sejam alcançados.

\section{Palavras-Chave}

Administração Pública; patente; proteção patentária; INPI; morosidade. 


\section{Sumário}

Introdução

6

Capítulo 1: Princípios da Administração Pública fundamentais à garantia do direito do inventor

1.1. A importância do estudo dos princípios ................................................. 9

1.2. Princípio da eficiência da Administração Pública .................................. 10

1.3. Princípio da duração razoável do processo administrativo ..................... 14

1.4. Princípio da segurança jurídica ............................................................ 16

\section{Capítulo 2: $O$ direito do inventor à proteção patentária}

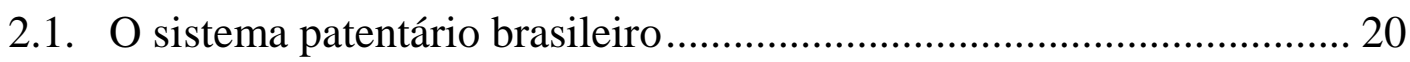

2.2. O procedimento administrativo de concessão de patentes.................... 28

Capítulo 3: A morosidade da Administração Pública na concessão de patentes

3.1. O backlog de pedidos de patentes no Brasil

3.2. A violação aos princípios constitucionais e o mandado de segurança

como instrumento para acelerar o exame dos pedidos de patente 45

Conclusão 58 


\section{Lista de abreviações}

CRFB/88 - Constituição da República Federativa do Brasil de 1988

INPI - Instituto Nacional de Propriedade Industrial

LPI - Lei de Propriedade Industrial

RPI - Revista da Propriedade Industrial

PI - Patente de invenção

MU - Modelo de utilidade

TRIPs - Acordo sobre Aspectos dos Direitos de Propriedade Intelectual Relacionados ao Comércio

DIRPA - Diretoria de Patentes, Programas de Computador e Topografias de Circuitos Integrados 


\section{Introdução}

O direito à proteção patentária está previsto no texto constitucional, em meio aos direitos e garantias individuais enumerados pelo art. $5^{\circ}$ da Constituição Federal, que determina, em seu inciso XXIX, que a lei assegurará aos autores de inventos industriais o privilégio temporário para a utilização de suas criações.

Como se vê, o dispositivo se dirige ao legislador, deixando a cargo da lei a garantia dos direitos de propriedade industrial. Além disso, o preceito constitucional estabelece fins específicos para essa proteção: preconizar pelo interesse social e favorecer o desenvolvimento tecnológico e econômico do país.

Assim, apesar de estar definido entre os direitos individuais, é evidente que o direito à proteção patentária possui cunho essencialmente econômico. A tutela ao espírito criador visa estabelecer uma política de ordem econômica, na qual o estímulo à inovação é a base fundamental para a promoção do desenvolvimento tecnológico e, consequentemente, do desenvolvimento da economia do país. Nesse sentido, José Afonso da Silva, ao tratar da propriedade intelectual, assevera que:

"O dispositivo que a define e assegura está entre os dos direitos individuais, sem razão plausível para isso, pois evidentemente não tem natureza de direito fundamental do homem. Caberia entre as normas da ordem econômica."

O incentivo aos investimentos das empresas e institutos de pesquisa no desenvolvimento da ciência e de novas tecnologias se dá através da concessão de patentes, que consiste em um direito de exclusividade temporária sobre a exploração do invento.

A proteção patentária está vinculada ao preenchimento de requisitos legais e será reconhecida, ou não, após o procedimento administrativo perante o

\footnotetext{
${ }^{1}$ Silva, José Afonso da. Curso de Direito Constitucional Positivo, 37 ${ }^{a}$ Edição, São Paulo: Malheiros, 2014, p. 280.
} 
INPI, autarquia federal responsável por examinar os pedidos de patente e expedir as cartas patente.

Ocorre que, na prática, o processo administrativo para a concessão de patentes no Brasil tem demorado em média uma década ${ }^{2}$. O INPI possui um backlog altíssimo, o que significa que esse atraso para a concessão de patentes enfrenta, além de tudo, a questão do acúmulo de trabalho pela autarquia. O termo "backlog” possui diversas acepções, mas, de forma breve, pode ser definido como o acúmulo de pedidos de patente pendentes de análise.

O problema da morosidade da Administração Pública no âmbito do sistema patentário se tornou um obstáculo ao processo de desenvolvimento do país, na medida em que a proteção dos direitos de propriedade industrial desempenha um papel importante no estímulo à atividade inventiva, capaz de gerar uma corrida pela inovação e, em consequência, promover o avanço tecnológico.

A demora no exame dos pedidos de patente não só prejudica o desenvolvimento tecnológico e econômico, mas também viola diversos princípios constitucionais que regem a atuação da Administração Pública.

Diante desse cenário, tem se tornado comum a impetração de mandado de segurança individual pelos depositantes de pedidos de patente a fim de acelerar o procedimento, com fundamento no direito à duração razoável do processo administrativo. Além da via judicial utilizada pelos próprios depositantes dos pedidos de patente, as autoridades administrativas têm debatido soluções que poderão amenizar o problema a curto prazo, como será visto no presente trabalho.

2 Dado constante do Relatório de Atividades 2017 do INPI. Disponível em: http://www.inpi.gov.br/sobre/estatisticas Acesso em: 05/05/2018. 
Por isso, é importante entender de que modo a demora na análise dos pedidos de patente viola os princípios constitucionais e tem forte impacto para os diversos agentes do mercado, afetando a sociedade como um todo e gerando essa necessidade de buscar soluções a curto e a longo prazo para o problema da morosidade da Administração Pública no exame de pedidos de patente.

Este trabalho irá, portanto, analisar a demora na análise dos pedidos de patente à luz dos princípios constitucionais da segurança jurídica, da duração razoável do processo administrativo e da eficiência da Administração Pública, bem como dos direitos de propriedade industrial.

Para tanto, analiso, no capítulo I, os princípios da eficiência, da duração razoável do processo administrativo e da segurança jurídica, de forma abstrata, para identificar suas principais características e expor seu papel no exercício das atividades exercidas pela Administração Pública.

No capítulo II, abordo as características e objetivos do sistema patentário brasileiro, bem como os principais pontos do processo administrativo de concessão de patentes, a fim de apresentar o objeto de análise do presente trabalho.

Por fim, no capítulo III, exponho os dados disponibilizados pelo INPI acerca do acúmulo de trabalho da autarquia para, então, analisar, à luz dos princípios da eficiência, da duração razoável do processo e da segurança jurídica, o problema da morosidade da Administração Pública no exame de pedidos de patente. 


\section{Capítulo 1: Princípios da Administração Pública fundamentais à garantia do direito do inventor}

\subsection{A importância do estudo dos princípios}

Para entender o propósito dos regimes jurídicos é preciso estudar os princípios que os fundamentam. Os princípios são normas genéricas e abstratas que formam o alicerce de um sistema jurídico, trazendo seus valores básicos e indicando como o direito positivo deve ser interpretado e aplicado.

Há princípios que se aplicam a todo e qualquer ramo do direito e outros que são específicos de determinada matéria. Vejamos, por exemplo, o princípio da dignidade da pessoa humana (art. $1^{\circ}$, III, da CRFB/88), que se aplica ao direito brasileiro, orientando a interpretação da Constituição e de toda a legislação infraconstitucional. Em contraposição, temos princípios específicos tanto expressos quanto implícitos - que fundamentam determinados ramos do direito, tais como o princípio da presunção de inocência no Direito Penal, o princípio da autotutela no Direito Administrativo e o princípio da prevenção no Direito Ambiental.

No âmbito do direito público, no qual está inserido o regime jurídico administrativo, o princípio da supremacia do interesse público sobre o particular é essencial para a interpretação e aplicação de toda e qualquer norma, principalmente dos demais princípios que orientam os diversos ramos do direito público.

A Administração Pública deve, então, ser estudada a partir da noção de que a sua atuação deve sempre buscar o interesse público. A interpretação e a aplicação de todo o regime jurídico administrativo, inclusive quando falamos de outros princípios da Administração Pública, devem ser pautadas na premissa de que o interesse público é o objetivo principal a ser atingido. 
A Constituição de 1988 faz expressa menção a cinco princípios da Administração Pública no caput do art. 37: os princípios da moralidade, da legalidade, da impessoalidade, da publicidade e da eficiência. Porém, estes não são os únicos princípios que regem a atuação da Administração Pública. Existem outros, alguns expressos e outros implícitos, que estão na Constituição ou, eventualmente, na legislação infraconstitucional.

Para abordar o problema da lentidão dos processos administrativos de concessão de patentes, não há como não falar em eficiência, celeridade e segurança jurídica. Por isso, trataremos aqui do princípio da eficiência, que deve guiar a gestão e o uso dos recursos públicos pela Administração Pública, do princípio da duração razoável do processo administrativo e do princípio da segurança jurídica.

\subsection{Princípio da eficiência da Administração Pública}

O princípio da eficiência não constava originalmente no rol do art. 37 da Constituição da República, que traz os princípios que regem a atuação da Administração Pública. A ideia de eficiência como princípio foi introduzida no texto constitucional posteriormente, através da Emenda 19/98 - a Emenda da reforma administrativa, que veio a incorporar à Administração Pública conceitos próprios da administração gerencial privada. A exposição de motivos da Emenda 19/98 deixa claro o intuito de implementar alterações direcionadas a um modelo administrativo menos engessado e mais ágil, falando em "revigoramento da capacidade de gestão" e colocando o aumento da eficiência do aparelho estatal como um dos pontos de partida para a melhoria pretendida ${ }^{3}$.

\footnotetext{
3 “O revigoramento da capacidade de gestão, de formulação e de implementação de políticas nos aparatos estatais será determinante para a retomada do desenvolvimento econômico e o atendimento às demandas da cidadania por um serviço público de melhor qualidade. Além disso, o aumento da
} 
Por óbvio, o dever de eficiência sempre foi inerente à função administrativa, pois uma Administração Pública ineficiente é inconcebível. Assim, antes de sua inclusão no caput do art. 37 da Constituição, era estudado como dever, e não como princípio. Isso não faria diferença em termos práticos, a princípio. No entanto, a sua inclusão como princípio veio colocar como alicerce do regime administrativo a lógica de que a administração deve produzir resultados satisfatórios.

Desse modo, o resultado passou a ser o norte da Administração Pública. O princípio da eficiência preconiza que os serviços públicos sejam executados com diligência, agilidade e economicidade. Para isso, os recursos públicos não podem ser desperdiçados e devem ser aplicados de maneira otimizada, buscando a produção dos melhores resultados com o menor custo possível. Nesse sentido, José Afonso da Silva ensina:

"Isso quer dizer, em suma, que a eficiência administrativa se obtém pelo melhor
emprego dos recursos e meios (humanos, materiais e institucionais) para melhor
satisfazer às necessidades coletivas num regime de igualdade dos usuários. Logo, o
princípio da eficiência administrativa consiste na organização racional dos meios e
recursos humanos, materiais e institucionais para a prestaçâo de serviços públicos de
qualidade com razoável rapidez, consoante previsão do inciso LXXVIII do art. $5^{\circ}$ (EC-
45/2004) e em condições econômicas de igualdade dos consumidores."

A gestão pública deve funcionar como qualquer outra gestão, isto é, com foco em resultados, buscando produtividade e economicidade. Porém, existe um elemento específico, que é essencial no âmbito da gestão pública: buscar os objetivos da lei, tendo sempre em vista o interesse público.

O interesse público é a base da atuação da Administração Pública. Para que ele seja atendido em suas diversas formas, é preciso que sejam garantidas,

eficiência do aparelho do Estado é essencial para a superação definitiva da crise fiscal." (grifos nossos) In: Legislação Informatizada - EMENDA CONSTITUCIONAL N 19, DE 1998 - Exposição de Motivos. Disponível em: http://www2.camara.leg.br/legin/fed/emecon/1998/emendaconstitucional-194-junho-1998-372816-exposicaodemotivos-148914-pl.html Acesso em: 28/05/2018.

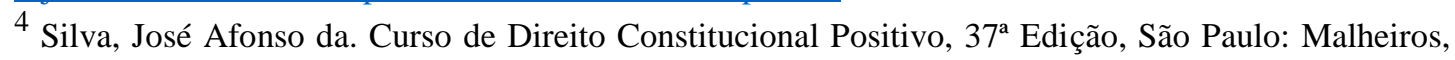
2014, p. 681. 
fundamentalmente, três condições básicas aos administrados: os serviços públicos devem ser prestados com qualidade e celeridade, seus usuários devem ser tratados com isonomia e terem assegurada sua segurança jurídica.

Nesse sentido, é importante ressaltar que foram criados alguns mecanismos para promover o princípio da eficiência, tais como a avaliação periódica de desempenho (art. $41, \S 1^{\circ}$, III, da CFRB/88), a possibilidade de aumentar a autonomia gerencial, orçamentária e financeira dos órgãos e entidades da Administração Pública (art. 37, $\S 8^{\circ}$, da CFRB/88) e a duração razoável do processo administrativo (art. 50, LXXVIII, da CFRB/88) que se consubstancia em um princípio que será estudado a seguir.

Apesar do princípio da eficiência ter trazido para o âmbito da Administração Pública ideias típicas da administração gerencial, sabemos que na prática não houve mudanças significativas na efetividade dos serviços públicos. Ainda observamos a lentidão e a burocracia características do setor público brasileiro.

As atividades destinadas à satisfação da coletividade são assumidas pelo Estado, que através de seus diversos órgãos e entidades distribui e descentraliza as funções administrativas. Esse modelo, em tese, auxiliaria o melhor desempenho dessas funções, uma vez que evitaria a sobrecarga de trabalho.

Ocorre que, na prática, os serviços públicos enfrentam problemas que surgem em virtude da má gestão. Os problemas ocorrem não só pela falta de recursos humanos ou financeiros, mas também pela falta de organização desses recursos - quando eles estão disponíveis - no sentido de promover o bom desempenho do serviço público.

Vemos isso com frequência, por exemplo, na área da saúde. A falta de médicos suficientes para atender a população de determinada região e a insuficiência de recursos nos hospitais é um problema que observamos há décadas e não conseguimos combater. Muitas vezes esse problema ocorre pura 
e simplesmente pelo desvio das verbas públicas destinadas à área da saúde e pelas fraudes de médicos que burlam o sistema de ponto. No entanto, sabemos que a má gestão está diretamente ligada a isso, assim como aos problemas de falta de recursos humanos e financeiros para a prestação dos serviços.

Uma boa gestão envolve não só os cuidados necessários para que não ocorram desvios e as funções sejam realizadas corretamente, mas também a organização dos recursos humanos, financeiros e materiais para que o serviço seja executado com qualidade e atenda à demanda da coletividade.

Todos esses problemas decorrentes da má-gestão no âmbito da Administração Pública - a falta de recursos, o mal gerenciamento dos recursos existentes e a desorganização - caracterizam a ineficiência da Administração Pública e causam, dentre outras coisas, a lentidão na execução das atividades.

Em relação ao Instituto Nacional de Propriedade Industrial (INPI) não é diferente, como veremos adiante. A lentidão dos processos administrativos de concessão de patentes é um problema diretamente ligado à questão da eficiência. O acúmulo de trabalho prejudica o desempenho das atividades da autarquia, que não possui recursos humanos suficientes para reverter esse quadro, gerando um problema sem fim.

Portanto, uma boa gestão pública é essencial para que as atividades do Estado sejam prestadas com qualidade, celeridade e atinjam o seu objetivo maior, que é o benefício da coletividade. Nesse sentido, o interesse público só será realizado se a Administração Pública produzir resultados efetivos no desempenho de suas atividades. Para tal, como vimos, faz-se necessário que a gestão pública seja pensada para realizar as atividades com qualidade e rapidez, reduzindo gastos na medida do possível e aumentando a produtividade. 


\subsection{Princípio da duração razoável do processo administrativo}

A emenda constitucional $n^{\circ} 45$ de 2004 incluiu o inciso LXXVIII no art. $5^{\circ}$ da Constituição, instituindo o princípio da duração razoável do processo ao dispor que "a todos, no âmbito judicial e administrativo, são assegurados a razoável duração do processo e os meios que garantam a celeridade de sua tramitação".

Observa-se, pela redação do referido dispositivo constitucional, que o princípio da duração razoável do processo é aplicável tanto na esfera judicial quanto na esfera administrativa. No processo judicial, o princípio objetiva, em suma, assegurar o direito de acesso à justiça, que possui como um de seus principais aspectos a prestação jurisdicional em tempo razoável para a garantia do direito pleiteado. No âmbito administrativo, por sua vez, a duração razoável do processo se configura como uma das dimensões do princípio da eficiência, pois a celeridade dos processos administrativos é elemento essencial para que a Administração Pública exerça suas funções com eficiência.

A grande questão no estudo do princípio da duração razoável do processo é a determinação do momento em que o tempo de tramitação do processo ultrapassa os limites do razoável e atenta contra a eficiência e o direito do administrado de obter uma resposta da Administração Pública em um prazo tolerável.

Essa é uma questão de difícil definição porque a razoabilidade é um conceito jurídico indeterminado, não havendo como precisar o tempo necessário para que se possa dizer que tal princípio está sendo violado.

A palavra razoável possui algumas acepções no dicionário, que giram em torno de noções como "racional", "aceitável" e "sensato". A partir disso, é possível definir como razoável aquilo que seja considerado aceitável pelo senso comum dentro de determinado contexto, em uma lógica racional e de acordo com as peculiaridades que uma situação envolva. Em outras palavras, para 
identificar algo como razoável é preciso analisar a situação, considerando o contexto em que ela se encontra para, a partir da racionalidade, concluir o que seria aceitável pelo senso comum.

Desse modo, faz-se necessária que haja uma valoração no momento da aplicação do princípio da duração razoável do processo administrativo para concluir se determinada demora está ou não dentro de um prazo razoável.

Apesar disso, a Lei 9.784/99, que regula o processo administrativo em âmbito federal, prevê em seu art. 49 o prazo de 30 dias, prorrogáveis por igual período, para que a Administração Pública decida após o fim da instrução do processo administrativo ${ }^{5}$. Entretanto, sabemos que a atividade administrativa no setor público é marcada, de forma geral, pela lentidão e burocracia nos procedimentos e que, portanto, esse prazo de 30 dias para decidir raramente é observado na maioria dos órgãos e entidades da Administração Pública.

Observamos, com certa frequência, uma demora excessiva dos órgãos e entidades para a conclusão dos processos administrativos e cumprimento das funções administrativas, o que não só viola o princípio da duração razoável do processo, mas, principalmente, gera ineficiência e corrói a credibilidade da Administração Pública perante a sociedade.

Dita demora, tendo em vista suas consequências e a relevância social das funções da Administração Pública, não é razoável na maioria das vezes, ainda que sejam justificadas pela falta de recursos humanos e financeiros. Isto porque, como visto no tópico anterior, a gestão deve ser organizada para promover a eficiência e garantir aos administrados o acesso aos seus direitos. Assim, a Administração Pública é responsável pela ausência de recursos suficientes ou má-gestão desses recursos para a realização das suas funções, sendo irrazoável

\footnotetext{
5 Art. 49. Concluída a instrução de processo administrativo, a Administração tem o prazo de até trinta dias para decidir, salvo prorrogação por igual período expressamente motivada. (Lei 9.784/99)
} 
a morosidade administrativa, ainda que decorrente desses problemas, posto que pode custar aos cidadãos a não garantia de seus direitos.

Ademais, a razoabilidade deve não só guiar a atuação dos agentes públicos para promover a eficiência nos processos administrativos e na prestação dos serviços públicos, mas também limitar eventual discricionariedade dos agentes públicos no exercício de suas funções, assegurando tratamento isonômico aos administrados.

Diante disso, a duração razoável do processo administrativo é importantíssima, na medida em que impõe a celeridade como princípio, permitindo que seja exigido do setor público uma atuação cada vez mais célere e produtiva, para que a eficiência se torne realidade no âmbito da Administração Pública.

\subsection{Princípio da segurança jurídica}

O princípio da segurança jurídica foi inserido entre os princípios da Administração Pública pelo artigo $2^{\circ}$, caput, da Lei 9.784/99, mas é certo que por tratar-se de um princípio geral de direito, decorrente do sistema constitucional, sempre possuiu grande importância no Direito Administrativo.

De acordo com Maria Sylvia Zanella Di Pietro, o que inspirou a inclusão do princípio na Lei Federal de Processo Administrativo foi a ideia de vedar a aplicação retroativa de nova interpretação de lei no âmbito da Administração Pública ${ }^{6}$. Em outras palavras, sua inclusão pretendeu impedir que a mudança da interpretação da lei retroaja a casos já decididos com base em interpretação anterior. Apesar disso, essa ideia não esgota todo o sentido do princípio da segurança jurídica, que possui múltiplos aspectos.

\footnotetext{
${ }^{6}$ Di Pietro, Maria Sylvia Zanella. Direito Administrativo, 27ª Edição, São Paulo: Atlas, 2014, p. 85.
} 
Em um Estado Democrático de Direito é preciso assegurar aos cidadãos a existência de instituições garantidoras dos direitos fundamentais - como o Judiciário e a Administração Pública - e a estabilidade das relações sociais. A noção de segurança jurídica engloba desde a clareza das normas jurídicas e o respeito às relações jurídicas criadas até a previsibilidade dos comportamentos adotados pelos agentes do Poder Judiciário e da Administração Pública na interpretação e aplicação das leis.

O princípio da segurança jurídica se expressa no ordenamento jurídico de diversas formas, como através do direito adquirido, da coisa julgada e do ato jurídico perfeito, que visam preservar a estabilidade dos direitos e, ainda, institutos como a prescrição e a decadência, a fim de impedir que os indivíduos sejam surpreendidos por litígios decorrentes de situações passadas longínquas, já superadas por força do decurso do tempo.

Nesse sentido, o instituto da decadência tem lugar no processo administrativo, tendo em vista que a segurança jurídica também precisa ser assegurada em relação aos atos administrativos. A Lei de Processo Administrativo prevê em seu art. 54 o prazo decadencial de cinco anos para a Administração Pública anular seus atos administrativos ilegais de que decorram efeitos favoráveis para os destinatários?

A atuação da Administração Pública deve ser coerente e isonômica no tratamento dado aos administrados a fim de que haja uma mínima previsibilidade em relação aos atos administrativos. Desse modo, é certo que o princípio da segurança jurídica está diretamente ligado à proteção da confiança legítima, na medida em que não se pode surpreender o administrado com um ato

\footnotetext{
7 Art. 54. O direito da Administração de anular os atos administrativos de que decorram efeitos favoráveis para os destinatários decai em cinco anos, contados da data em que foram praticados, salvo comprovada má-fé. (Lei 9.784/99)
} 
absolutamente inesperado, em contradição à comportamento anterior da Administração.

Ademais, a segurança jurídica é essencial para que os indivíduos elaborem planejamentos e conduzam suas vidas, posto que na tomada de decisões levam em conta as previsões daquilo que consideram que está por vir. Tais considerações são feitas com base na atuação reiterada de um órgão ou entidade, e, principalmente, a partir do que a lei determina para a atuação da Administração Pública. Daí a importância da clareza das leis e do respeito aos comandos normativos quando da interpretação e aplicação destas leis pela Administração. Conforme os ensinamentos de Celso Antônio Bandeira de Mello, a ação humana é condicionada por esta previsibilidade em relação ao futuro:

'Esta 'segurança jurídica' coincide com uma das mais profundas aspirações do Homem: a da segurança em si mesma, a da certeza possível em relação ao que o cerca, sendo esta uma busca permanente do ser humano. É a insopitável necessidade de poder assentar-se sobre algo reconhecido como estável, ou relativamente estável, o que permite vislumbrar com alguma previsibilidade o futuro; é ela, pois, que enseja projetar e iniciar, consequentemente - e não aleatoriamente, ao mero sabor do acaso -, comportamentos cujos frutos são esperáveis a médio e longo prazo. Dita previsibilidade é, portanto, o que condiciona a ação humana. Esta é a normalidade das coisas." 8

Diante disso, é necessário que a Administração Pública atue em conformidade com as normas e princípios que guiam o regime administrativo. Não só em virtude do princípio da legalidade, que é a base desse regime, mas também para que a segurança jurídica dos administrados seja garantida. Quando a Administração Pública atua em desconformidade com aquilo que está previsto no ordenamento jurídico, a legítima expectativa dos administrados é frustrada.

A lentidão na análise dos pedidos de concessão de patente, questão objeto do presente trabalho, é um exemplo de atuação da Administração Pública em

\footnotetext{
${ }^{8}$ Bandeira de Mello, Celso Antônio. Curso de Direito Administrativo, 33a Edição, São Paulo: Malheiros, 2017, p. 128.
} 
desconformidade com a lei e, principalmente, com os princípios constitucionais, que gera grande insegurança jurídica, como veremos. Isto porque os inventores investem tempo, dinheiro e conhecimento para a criação de produtos inovadores e, em virtude da morosidade administrativa, levam anos para ter a garantia da proteção patentária, assegurada constitucionalmente e regulamentada na legislação infraconstitucional.

Assim, o princípio da segurança jurídica possui papel fundamental no regime administrativo não só para proteger a confiança legítima dos administrados e o respeito às relações jurídicas existentes, mas também para assegurar a previsibilidade dos administrados acerca da interpretação e aplicação das leis pela Administração Pública, que deve sempre agir em conformidade com a lei e, principalmente, com os princípios constitucionais que regem sua atuação. 


\section{Capítulo 2: 0 direito do inventor à proteção patentária}

\subsection{O sistema patentário brasileiro}

A atividade criadora do homem é a grande responsável pela evolução da sociedade. A invenção da locomotiva e do telefone, no século XIX, nos trouxe, rapidamente, à era dos trens-bala e smartphones. Os inventos impulsionam o desenvolvimento social e econômico, trazendo benefícios imensuráveis para a sociedade: através da ação humana atingimos níveis impensáveis de desenvolvimento em um curto espaço de tempo. $\mathrm{Na}$ área da saúde, por exemplo, a invenção de um medicamento pode significar a cura para uma doença até então fatal.

Assim, por trás do interesse econômico de uma farmacêutica ou de um grupo de pesquisa científica que investe em uma criação desse porte, há o interesse público na produção de um medicamento que pode salvar vidas. Por isso, a ponderação de interesses é crucial para o funcionamento de um sistema patentário que, ao mesmo tempo, proteja o interesse público - garantindo o acesso da sociedade aos inventos - e estimule a continuidade dos investimentos para a criação de produtos inovadores.

Isto porque, se por um lado os inventos trazem muitos benefícios à sociedade, por outro lado são extremamente custosos para o inventor. Anos de pesquisa e investimento na realização de uma inovação que poderá ser aproveitada por toda a sociedade merecem alguma compensação.

A forma adotada pelo Brasil para preservar, na medida do possível, ambos os interesses é a concessão do registro da patente pelo Instituto Nacional de Propriedade Industrial (INPI). Apesar de consistir na criação de um monopólio legal que exclui temporariamente a competição, é uma estratégia capaz de efetivamente gerar incentivo à produção dos bens intelectuais. 
A concessão da patente é um direito do inventor derivado do regime da Propriedade Intelectual, que protege os bens intelectuais, englobando dois grandes ramos 9 : a Propriedade Industrial e o Direito Autoral.

A instituição da proteção aos bens intelectuais é uma medida de cunho essencialmente econômico: a tutela ao espírito criador está diretamente ligada ao desenvolvimento de um país. O texto constitucional não deixa dúvidas acerca da importância dessa proteção ao reconhecer o direito constitucional de exclusividade sobre as criações intelectuais.

A intervenção do Estado através da proteção aos bens intelectuais é necessária para restringir a cópia. A exclusividade concedida pelo Estado é o meio de impedir que o espírito criador seja freado pela liberdade de cópia, que desestimularia os investimentos nas criações de bens intelectuais, como leciona Denis Borges Barbosa:

"Deixado à liberdade do mercado, o investimento na criação do bem intelectual seria imediatamente dissipado pela liberdade de cópia. As forças livres do mercado fariam com que a competição - e os mais aptos nela - absorvessem imediatamente as inovações e as novas obras intelectuais" 10

É certo que nem todas as criações surgem a partir da criatividade do ser humano. Enquanto o Direito do Autor protege as obras intelectuais que surgem tão somente da mente humana em um lapso criativo, a Propriedade Industrial protege as criações que se dão através da combinação do espírito criativo do homem com a aplicação de conhecimentos técnicos sobre elementos já existentes. Tais criações são possíveis graças às ideias e conhecimentos acumulados pela humanidade ao longo do tempo. $\mathrm{O}$ inventor atua com base

\footnotetext{
${ }^{9}$ É importante ressaltar que essa é a divisão tradicional da Propriedade Intelectual, que se tornou muito mais complexa após o acordo TRIPs, ratificado pelo Brasil em 1994. Para atender às exigências definidas no acordo TRIPs, o Brasil criou legislação específica para a proteção dos cultivares e dos software.

${ }^{10}$ Barbosa, Denis Borges. Uma Introdução à Propriedade Intelectual, $2^{\text {a }}$ Edição Revista e Atualizada, versão digital disponibilizada segundo os termos da licença Attribution-NonCommercial-NoDerivs 2.0 Generic (CC BYNC- ND 2.0), conforme http://creativecommons.org/licenses/by-ncnd/2.0/, p. 85 e 86. Disponível em: http://www.nbb.com.br/pub/denis/introducao_pi.pdf Acesso em: 30/04/2018.
} 
naquilo que já existe - que constitui o chamado estado da técnica ${ }^{11}$-, sendo certo que o pontapé inicial para a criação de um novo produto é o repositório de ideias, produtos e processos já existentes.

Nesse sentido, há uma importante distinção feita por Denis Borges Barbosa em sua obra "Uma Introdução à Propriedade Intelectual”, no que tange aos termos invento e invenção. Segundo o autor, invento é "uma solução técnica para um problema técnico" "12, enquanto invenção é a "criação industrial maior, objeto da patente de invenção, à qual, tradicionalmente, se concede prazo maior e mais amplidão de proteção" 13 .

Invenção, portanto, é termo mais específico, tratando-se de uma criação que deriva não só do espírito criativo, mas principalmente da aplicação de conhecimentos técnicos para a formação de um novo produto ou processo industrial. O termo invento, por sua vez, engloba tanto as invenções quanto as soluções técnicas de aprimoramento daquilo que já existe.

No regime da Propriedade Industrial, como veremos adiante, os inventos podem ser protegidos por patente de invenção ou modelo de utilidade, conforme consistam em um novo produto ou processo (patente de invenção) ou em um aperfeiçoamento de produto ou processo já existente (modelo de utilidade).

A patente é o instrumento jurídico que protege o invento ${ }^{14}$ e garante ao seu titular uma exclusividade temporária sobre a sua exploração. Trata-se, assim,

\footnotetext{
${ }^{11} \mathrm{O}$ estado da técnica é tudo aquilo tornado acessível ao público antes da data do depósito de um pedido de patente.

12 Barbosa, Denis Borges. Uma Introdução à Propriedade Intelectual, 2a Edição Revista e Atualizada, versão digital disponibilizada segundo os termos da licença Attribution-NonCommercial-NoDerivs 2.0 Generic (CC BYNC- ND 2.0), conforme http://creativecommons.org/licenses/by-ncnd/2.0/ , p. 296. Disponível em: http://www.nbb.com.br/pub/denis/introducao_pi.pdf Acesso em: 30/04/2018.

${ }^{13}$ Ibid., p. 296.

${ }^{14}$ Adotarei nesse trabalho o conceito trazido por Denis Borges Barbosa: utilizarei o termo genérico "invento" para se referir indistintamente, de forma genérica, às invenções e aos modelos de utilidade.
} 
de um privilégio ${ }^{15}$ temporário aos inventores, através do qual eles possuem o monopólio por tempo determinado sobre a exploração do invento.

O direito à proteção patentária é reconhecido pelo art. $5^{\circ}$ da Constituição Federal que, ao enumerar os direitos e garantias fundamentais, determina, em seu inciso XXIX, que a lei assegurará aos autores de inventos industriais o privilégio temporário para a utilização de suas criações.

"Art. 50.

(...)

XXIX - a lei assegurará aos autores de inventos industriais privilégio temporário para sua utilização, bem como proteção às criações industriais, à propriedade das marcas, aos nomes de empresas e a outros signos distintivos, tendo em vista o interesse social e o desenvolvimento tecnológico e econômico do País;

$(\ldots) "$

Como se vê, o dispositivo deixa a cargo da lei a garantia do direito nele reconhecido. Hoje, a Lei de Propriedade Industrial (Lei 9.279/96) regula os direitos relativos à propriedade industrial em substituição ao Código de Propriedade Industrial (Lei 5.772/71). Além disso, o preceito constitucional, ao se dirigir ao legislador, também estabelece fins específicos para essa proteção: preconizar pelo interesse social e favorecer o desenvolvimento tecnológico e econômico do país.

Conforme pode ser extraído da Constituição de 1988, o sistema patentário brasileiro foi concebido com a finalidade de promover o desenvolvimento científico, tecnológico e econômico do país, através do fomento à criação de novas tecnologias e à melhoria das tecnologias já existentes.

\footnotetext{
${ }^{15}$ Apesar do uso do termo privilégio ser utilizado pelos doutrinadores para a definição do direito à proteção patentária, vale ressaltar aqui o significado da palavra privilégio, que acabou por tornar-se uma palavra com conotação negativa frente ao senso comum: privilégio é uma condição de vantagem atribuída a uma pessoa ou grupo de pessoas. O privilégio tratado aqui é uma prerrogativa dada a um grupo de pessoas - os inventores -, de ter exclusividade temporária sobre a exploração de suas próprias invenções.
} 
Considerando que as pesquisas científicas e o desenvolvimento de novas tecnologias exigem investimentos contínuos e elevados ao longo do tempo, a concessão da exclusividade temporária aos inventores é elemento essencial do sistema patentário, na medida em que incentiva a prospecção tecnológica de empresas e institutos de pesquisas que investem no campo científico e tecnológico, contribuindo não só para a inovação, mas também para o desenvolvimento econômico do país.

A exclusividade temporária do inventor pode parecer, à primeira vista, uma vantagem indevida. Principalmente quando falamos em invenções na área da saúde, cuja exclusividade "atrasaria" a entrada do produto em domínio público e, consequentemente, prorrogaria o monopólio do titular da patente na exploração econômica de um medicamento ou de uma vacina, por exemplo.

No entanto, é preciso lembrar que a criação de um produto inovador, seja ele qual for, na maior parte das vezes envolve um planejamento de empresas ou institutos de pesquisa, que investem grandes montantes durante anos, sem qualquer retorno econômico. A concessão da patente se justifica porque é a melhor forma de garantir que esse investimento será recompensado no futuro, quando o invento for comercializado. A partir disso, investir em inovações passa a ser muito mais interessante do que seria caso o invento pudesse ser imediatamente explorado por todos.

Ressalta-se, por ser de extrema importância, que a patente possui prazo de validade, como será visto mais adiante. Isso significa que o privilégio do inventor não é eterno, pois findo o prazo de validade da patente o invento entra em domínio público e todos podem explorá-lo livremente.

Não se trata, portanto, de uma vantagem infundada, mas sim de uma recompensa justa, capaz de preservar o espírito inventivo. Estimular a criação de novas tecnologias, vale ressaltar, é também interesse da coletividade, que só tem a ganhar com o avanço tecnológico e científico do país. 
O grande obstáculo no que tange a legitimidade desse sistema de exclusividade estaria na livre concorrência como princípio básico da ordem econômica.

Nesse sentido, importa realçar que a Constituição dá ao Estado a função de agente normativo e fiscalizador, preconizando em seu art. 174 que cabe ao Estado fiscalizar, incentivar e planejar a atividade econômica. Além disso, o art. 219 da Carta prevê que o mercado interno será incentivado de forma a viabilizar o desenvolvimento cultural e socioeconômico, o bem-estar da população e a autonomia tecnológica do país.

A leitura desses dispositivos em conjunto com o art. $5^{\circ}$, XXIX, nos mostra que a solução encontrada para satisfazer os objetivos pretendidos pela Constituição da República foi justamente a restrição à concorrência como forma de proteção ao inventor, sistema adotado por todos os países:

"Se a legitimidade do direito do inventor e a necessidade de sua proteção pelo Estado são questões que não mais se discutem, assim também o privilégio temporário que as leis lhe conferem é, no consenso geral, a forma ou o meio mais adequado e mais equitativo de se lhe assegurar a propriedade do invento. É o sistema seguido pela legislação de todos os países, o que demonstra que o problema da proteção do direito do inventor, posto nos mesmos termos, em cada um deles, recebeu em todos solução idêntica. Deve-se, pois, concluir que o sistema dos privilégios é o único praticável ou, pelo menos, o mais justo e conveniente."16

Para compatibilizar a livre concorrência com a proteção aos bens intelectuais é preciso compreender que o constituinte não pretendeu afastar por completo a primeira, mas sim instituiu uma restrição temporária a ela em prol do desenvolvimento tecnológico e econômico do país. Como bem aponta Denis Borges Barbosa em seus ensinamentos, "a chave da propriedade intelectual é

\footnotetext{
${ }^{16}$ Cerqueira, João da Gama. Tratado da Propriedade Industrial, Volume I, Parte I: Da Propriedade Industrial e do Objeto dos Direitos. Rio de Janeiro: Editora Lumen Juris, 2010. P. 134.
} 
que fora dos limites muito estritos da proteção concedida, o público tem direito livre de copiar" ${ }^{\prime 17}$.

Além disso, a proibição de exploração de um invento patenteado não é absoluta: através da negociação com o inventor para o pagamento de royalties pela exploração de seu invento, é possível explorá-lo comercialmente já durante a vigência do prazo de validade da patente.

Outro elemento importante para entender a lógica do sistema de patentes é a publicação do pedido de patente, que faz com que o conteúdo do invento passe a ser conhecido pelo público logo no início do procedimento administrativo no INPI, como será visto mais adiante.

Desse modo, para receber a proteção patentária o inventor tornará pública a solução técnica encontrada para o problema técnico, uma vez que o pedido de patente depositado será publicado. A partir disso, o invento passa a fazer parte do "estado da técnica" e pode servir como base para possíveis melhorias e novas soluções. A inclusão do invento no estado da técnica é capaz de estimular uma "corrida" ao encontro de uma solução técnica ainda melhor por aqueles que investem seu tempo e dinheiro nisso, corrida esta que poderá trazer mais inovação, beneficiando mais uma vez toda a coletividade.

Nesse sentido, faz-se necessário lembrar que existem dois tipos de patentes: as patentes de invenção (PI), que protegem novas soluções para um problema técnico específico; e as patentes de modelo de utilidade (MU), que protegem melhorias funcionais no uso ou na fabricação dessa solução já existente.

\footnotetext{
${ }^{17}$ Barbosa, Denis Borges. Uma Introdução à Propriedade Intelectual, $2^{a}$ Edição Revista e Atualizada, versão digital disponibilizada segundo os termos da licença Attribution-NonCommercial-NoDerivs 2.0 Generic (CC BYNC- ND 2.0), conforme http://creativecommons.org/licenses/by-ncnd/2.0/, p. 93. Disponível em: http://www.nbb.com.br/pub/denis/introducao_pi.pdf Acesso em: 30/04/2018.
} 
O prazo de validade das patentes de invenção é de 20 anos e das patentes de modelo de utilidade é de 15 anos. Ao prever esses prazos, o legislador fez uma distinção clara na proteção da invenção e do modelo de utilidade, já que a primeira possui um grau de inventividade muito maior do que o segundo. $\mathrm{O}$ marco inicial do prazo de proteção é a data do depósito, conforme determinado pelo caput do art. 40 da LPI.

No entanto, o parágrafo único do mesmo dispositivo ${ }^{18}$ prevê que "o prazo de vigência não será inferior a 10 (dez) anos para a patente de invenção e 7 (sete) anos para a patente de modelo de utilidade, a contar da data da concessão, ressalvada a hipótese de o INPI estar impedido de proceder ao exame de mérito do pedido, por pendência judicial comprovada ou por motivo de força maior".

A Lei, através dessa previsão, praticamente assume que o procedimento administrativo de concessão da patente pode demorar muito para chegar ao fim e busca garantir o direito constitucional de exclusividade temporária do inventor assegurando um prazo mínimo para que ele usufrua de seus direitos. Assim, caso uma patente seja concedida mais de 10 anos após o depósito do pedido, o inventor tem a garantia de que ela ainda terá vigência por pelo menos 10 anos após a sua concessão. Importa ressaltar que, como explica Denis Borges Barbosa, "o direito ao privilégio propriamente dito nascerá, ou não, ao fim da prestação administrativa de exame e concessão descrita nesta Lei",19.

Portanto, o prazo de vigência irá variar a depender do tipo de patente em questão: as patentes de invenção vigoram pelo prazo máximo de 20 anos e

\footnotetext{
${ }^{18}$ Foram ajuizadas duas ADIs questionando a constitucionalidade do parágrafo único do art. 40 da LPI, que ainda não foram julgadas: ADI 5.061 e ADI 5.529. Disponível em: http://portal.stf.jus.br/processos/detalhe.asp?incidente $=4490434$ http://portal.stf.jus.br/processos/detalhe.asp?incidente $=4984195$, respectivamente. Acesso em: 28/05/2018.

${ }_{19}$ Barbosa, Denis Borges. "Bases Constitucionais da Propriedade Intelectual”, p. 22. Disponível em: http://www.nbb.com.br/pub/propriedade13.pdf Acesso em: 27/05/2018.
} 
mínimo de 10 anos, enquanto os modelos de utilidade vigoram pelo prazo máximo de 15 anos e mínimo de 7 anos (art. 40 da LPI).

As peculiaridades desse procedimento de concessão de patentes serão analisadas no próximo tópico.

\subsection{O procedimento administrativo de concessão de patentes}

A proteção patentária tem início com a concessão da patente, instrumentalizada através da carta-patente, documento que confere o privilégio temporário sobre a utilização e exploração da criação ao titular da patente, determinando a data inicial e a data final do prazo de vigência da proteção.

A competência para examinar os pedidos de patente e expedir as cartas patente é exclusiva do Instituto Nacional de Propriedade Industrial - INPI, autarquia federal vinculada ao Ministério do Desenvolvimento, Indústria e Comércio Exterior (MDIC). O procedimento tem início com o depósito do pedido de patente pelo requerente, que deverá apresentar todas as informações técnicas necessárias acerca do objeto do pedido para que o INPI analise a presença dos três requisitos para a concessão da proteção: novidade (art. 11 da LPI), atividade inventiva (arts. 13 e 14 da LPI) e aplicação industrial (art. 15 da LPI).

O requisito da novidade está diretamente ligado à noção de estado da técnica, pois a novidade diz respeito a fatos como o uso, a publicação ou a divulgação da tecnologia criada. O estado da técnica ${ }^{20}$, nos termos legais, compreende tudo aquilo que era de conhecimento do público até o momento do depósito da patente, seja através de forma escrita ou oral, pelo uso anterior da

\footnotetext{
${ }^{20}$ Art. 11. A invenção e o modelo de utilidade são considerados novos quando não compreendidos no estado da técnica.

$\S 1^{\circ} \mathrm{O}$ estado da técnica é constituído por tudo aquilo tornado acessível ao público antes da data de depósito do pedido de patente, por descrição escrita ou oral, por uso ou qualquer outro meio, no Brasil ou no exterior, ressalvado o disposto nos arts. 12, 16 e 17. (Lei 9.279/96)
} 
tecnologia ou simples divulgação. Nesse sentido, vejamos a lição de Denis Borges Barbosa:

O requisito de novidade das patentes é não só constitucional, mas na verdade ligado ao princípio fundamental da livre concorrência. Só aquilo que ainda não caiu no domínio público pode receber a exclusividade legal sem violar a liberdade da concorrência. ${ }^{21}$

O Brasil segue o princípio da novidade absoluta: a tecnologia para a qual se requer a proteção patentária não pode ter sido divulgada em lugar algum para que seja considerada nova. A análise que se faz, portanto, considera o estado da técnica sem limites territoriais, sendo certo que a existência de patente ou qualquer forma de divulgação ou uso da tecnologia fora do país é suficiente para comprometer o requisito da novidade.

O requisito da atividade inventiva, por sua vez, é verificado por meio da análise da ação humana sobre o problema técnico para o qual se propõe a solução. Para que haja atividade inventiva, a solução encontrada não pode ser óbvia para um técnico no assunto, considerando o estado da técnica. Ou seja, o inventor deve ter chegado àquela solução técnica a partir de um ato de criação.

Por fim, o requisito da aplicação industrial está relacionado com a viabilidade de produção ou utilização do invento na indústria. Restará atendido o requisito sempre que o invento puder ser produzido ou utilizado em qualquer tipo de indústria.

Em suma, o titular deve demonstrar (i) que a invenção nunca foi realizada, executada ou usada anteriormente, (ii) que o seu desenvolvimento não decorre de maneira óbvia do estado da técnica e, por fim, (iii) que a invenção pode ser produzida ou utilizada em qualquer tipo de indústria. Ao final do procedimento,

\footnotetext{
${ }^{21}$ Barbosa, Denis Borges. "Bases Constitucionais da Propriedade Intelectual”, p. 23. Disponível em: http://www.nbb.com.br/pub/propriedade13.pdf Acesso em: 27/05/2018.
} 
estando presentes esses requisitos, o INPI concederá o privilégio temporário ao titular da patente.

Há que se observar também que nem todo invento poderá ser patenteado. $\mathrm{O}$ art. 18 da LPI prevê que não serão patenteáveis o que for contrário à moral, aos bons costumes e à segurança, à ordem e à saúde públicas (inciso I); as substâncias, matérias, misturas, elementos ou produtos de qualquer espécie, bem como a modificação de suas propriedades físico-químicas e os respectivos processos de obtenção ou modificação, quando resultantes de transformação do núcleo atômico (inciso II); e o todo ou parte dos seres vivos, exceto os microorganismos transgênicos que atendam aos três requisitos de patenteabilidade novidade, atividade inventiva e aplicação industrial - previstos no art. $8^{\circ}$ e que não sejam mera descoberta (inciso III).

Além disso, o art. 10 da LPI traz um rol de tudo aquilo que não é considerado invenção ou modelo de utilidade e que, consequentemente, não poderá ser objeto de pedido de patente perante o INPI: descobertas, teorias científicas e métodos matemáticos (inciso I); concepções puramente abstratas (inciso II); esquemas, planos, princípios ou métodos comerciais, contábeis, financeiros, educativos, publicitários, de sorteio e de fiscalização (inciso III); obras literárias, arquitetônicas, artísticas e científicas ou qualquer criação estética (inciso IV); programas de computador em si (inciso V); apresentação de informações (inciso VI); regras de jogo (inciso VII); técnicas e métodos operatórios ou cirúrgicos, bem como métodos terapêuticos ou de diagnóstico, para aplicação no corpo humano ou animal (inciso VIII); e o todo ou parte de seres vivos naturais e materiais biológicos encontrados na natureza, ou ainda que dela isolados, inclusive o genoma ou germoplasma de qualquer ser vivo natural e os processos biológicos naturais (inciso IX).

A concessão da patente de invenção ou de modelo de utilidade, portanto, não ocorre de forma automática após o requerimento do inventor. Há um 
procedimento administrativo no INPI para que seja analisada a patenteabilidade do invento pelos agentes de propriedade industrial, que são especialistas capazes de verificar se os requisitos de patenteabilidade e as condições do pedido de patente estão ou não presentes.

É certo que o procedimento administrativo no INPI deve observar o devido processo legal, respeitando-se a publicidade dos atos administrativos, o contraditório, a ampla defesa e a razoável duração do processo. Na prática, veremos mais adiante que se trata de um procedimento extremamente lento, que perdura por diversos anos.

O procedimento se inicia com o depósito do pedido de patente no INPI. O depósito pode ser nacional ou ocorrer via PCT, tendo em vista que o Brasil é um dos signatários do Tratado de Cooperação em Matéria de Patente (PCT).

O depósito internacional via PCT possibilita que através de um único depósito preliminar - realizado em um dos países signatários do referido tratado -, o titular possua um prazo de 30 meses para estender o depósito aos demais países indicados no pedido, através do requerimento de entrada em fase nacional. A partir da entrada em fase nacional, o pedido de patente será processado no órgão competente naquele país. Durante a fase internacional, são realizadas as buscas de anterioridade internacionais, a fim de avaliar, de forma preliminar, o potencial do pedido em cada um dos países nos quais se pretende processar o pedido de patente.

A análise do pedido de patente pelo INPI se dá em duas fases: primeiro, há um exame preliminar, através do qual serão analisadas as questões formais do pedido de patente. Esse exame diz respeito às condições previstas no art. 19 da LPI, segundo o qual o pedido de patente deve conter o requerimento, um relatório descritivo, as reivindicações, os desenhos (facultativos), um resumo e o comprovante de pagamento da retribuição relativa ao depósito. 
O relatório descritivo é a base do pedido, pois descreve (i) o problema técnico para o qual se propõe a solução, (ii) o estado da técnica, ou seja, as soluções técnicas já existentes para aquele problema, e (iii) o invento em si, isto é, a nova solução técnica encontrada. O art. 24 da LPI prevê que o relatório descritivo deve descrever "clara e suficientemente o objeto, de modo a possibilitar sua realização por técnico no assunto e indicar, quando for o caso, a melhor forma de execução".

As reivindicações, por sua vez, caracterizam todas as particularidades do invento, delimitando a extensão da proteção patentária pretendida. Em suma, as reivindicações devem definir, com exatidão e clareza, todas as especificidades da invenção para as quais a proteção é requerida. Durante o procedimento no INPI, o quadro reivindicatório pode sofrer alterações, mas apenas no sentido de melhor precisar ou restringir o escopo da proteção, não sendo possível modificações que configurem um aumento no escopo da matéria a ser protegida.

Diversamente dos demais elementos do pedido de patente, a apresentação dos desenhos não é obrigatória. No entanto, quando apresentados, irão servir como base para a interpretação das reivindicações, na medida em que permitem a visualização das informações técnicas relativas ao invento.

O resumo, por fim, deve constituir uma síntese daquilo que foi exposto no relatório descritivo, nas reivindicações e nos desenhos, indicando de forma sucinta o problema técnico e a essência da solução técnica proposta, permitindo a compreensão do avanço técnico promovido pela invenção ${ }^{22}$. Ele deverá conter informações suficientes para que um terceiro possa, tão somente através do resumo, discernir quanto a necessidade ou não de consultar a íntegra do pedido de patente.

\footnotetext{
${ }^{22}$ IDS - Instituto Dannemann Siemsen de Estudos de Propriedade Intelectual.Comentários à Lei de Propriedade Industrial, Edição Revista e Atualizada, Rio de Janeiro: Renovar, 2005, p. 50.
} 
Se o pedido estiver devidamente instruído, passa-se à fase de análise técnica do pedido. Caso contrário, o art. 21 da LPI traz a possibilidade de complementar o pedido posteriormente, determinando que o INPI receba o pedido e assinale prazo para o cumprimento de exigências. Assim, diante da ausência de algum documento, estando presentes os dados relativos ao objeto, ao inventor e ao depositante, o INPI irá estabelecer as exigências formais a serem cumpridas no prazo de 30 dias.

O INPI mantém o pedido de patente em sigilo durante o período de 18 (dezoito) meses, contados da data do depósito ou da prioridade mais antiga, quando houver, conforme prevê o art. 30 da LPI. Com a publicação do pedido na Revista de Propriedade Industrial (RPI) - publicação oficial do INPI -, as cópias do relatório descritivo, das reivindicações, do resumo e dos desenhos ficam à disposição do público.

É possível, no entanto, que o titular do pedido antecipe a publicação, a fim de agilizar o procedimento, tendo em vista que o parágrafo único do artigo 31 da LPI determina que o exame técnico do pedido não poderá ser iniciado antes de 60 dias da publicação. Apesar dessa previsão ser contrária ao espírito da celeridade no procedimento, na medida em que obrigatoriamente atrasa o início do exame do pedido, a regra foi instituída a fim de estabelecer um período mínimo entre a publicação e o início do exame para que terceiros possam tomar conhecimento do pedido e preparar eventuais objeções:

"De fato, no que concerne a terceiros que desejam contestar a validade de um pedido, é necessário tempo hábil, a partir da publicação do pedido, para reunir e preparar os documentos e/ou informações que consubstanciem sua pretensão." 33

O exame técnico se inicia com o requerimento de exame que deverá ser apresentado pelo titular do pedido, dentro de 36 (trinta e seis) meses, contados

\footnotetext{
${ }^{23}$ IDS - Instituo Dannemann Siemsen de Estudos de Propriedade Intelectual. Comentários à Lei de Propriedade Industrial, Edição Revista e Atualizada, Rio de Janeiro: Renovar, 2005, p. 65.
} 
da data do depósito, com a referida ressalva de que não será iniciado antes de 60 dias da publicação na Revista de Propriedade Industrial. O depositante terá até o requerimento do exame para efetuar eventuais alterações a fim de melhor esclarecer ou definir o pedido de patente, limitadas à matéria inicialmente revelada no pedido (artigo 32 da LPI).

A necessidade de requerimento soa estranha, uma vez que se o autor depositou o pedido de patente, significa que deseja que seu pedido seja analisado e concedido pelo INPI. Contudo, trata-se de uma opção sensata do legislador, a fim de evitar que a autarquia inicie o exame de pedidos relativos a inventos que já se tornaram obsoletos no momento do início do exame. André Luiz Santa Cruz Ramos e Thiago Martins Guterres explicam:

"É que muitas vezes os pedidos de patente, após o depósito, perdem o objeto, provocando o desinteresse dos próprios inventores. Isso ocorre porque a velocidade do desenvolvimento tecnológico e científico atingiu um grau tão espetacular que, não raro, uma invenção é superada por outra em curtíssimo espaço de tempo, tornando-se obsoleta. Por essa razão, criou-se a regra ora em comento, que fez com que o INPI somente passasse a examinar pedidos de patente de inventos que, mesmo após algum tempo da sua criação, continuassem sendo interessantes para o inventor." 24

Essa regra contribui para a celeridade, uma vez que o INPI somente examina os inventos diante do requerimento formal de exame dentro do prazo legal. Caso contrário, o pedido é arquivado e, a princípio, não será examinado pela autarquia ${ }^{25}$. Não obstante, é interessante observar que através dessa regra o legislador praticamente assumiu que o início do exame técnico pelo INPI pode demorar a ponto de o invento tornar-se obsoleto.

Diante do requerimento de exame, o INPI irá iniciar o exame técnico do pedido. Além dos requisitos de patenteabilidade (novidade, atividade inventiva

\footnotetext{
${ }^{24}$ Ramos, André Luiz Santa Cruz. Guterres, Thiago Martins. Lei de Propriedade Industrial Comentada: Lei 9.279, de 14 de maio de 1996. Salvador: Editora JusPodivm, 2016, p. 97.

${ }^{25}$ O parágrafo único do art. 33 da LPI (Lei 9.279/96) prevê a possibilidade de desarquivamento do pedido: "o pedido de patente poderá ser desarquivado, se o depositante assim o requerer, dentro de 60 (sessenta) dias contados do arquivamento, mediante pagamento de uma retribuição específica, sob pena de arquivamento definitivo".
} 
e aplicação industrial), também serão consideradas a unidade do pedido ${ }^{26}$, a suficiência descritiva e a clareza e precisão das reivindicações, sendo certo que a ausência de qualquer dessas condições pode gerar a nulidade da patente.

Feito o exame, será elaborado parecer técnico relativo à patenteabilidade do pedido, adaptação do pedido à natureza reivindicada, reformulação do pedido ou divisão ${ }^{27}$ e formulação de exigências técnicas, conforme o art. 35 da LPI. O parecer do INPI, portanto, poderá concluir pela patenteabilidade do pedido, pela não patenteabilidade do pedido ou pela necessidade de (i) adaptação do pedido à natureza reivindicada, (ii) reformulação do pedido ou divisão do mesmo, ou (iii) cumprimento de exigências técnicas.

O depositante terá sempre o prazo de 90 (noventa) dias, determinado no art. 36 da LPI, para responder as exigências técnicas formuladas pelos examinadores e apresentar suas manifestações aos pareceres técnicos. Caso o depositante não responda às exigências técnicas no prazo legal, o pedido será definitivamente arquivado (art. $36, \S 1^{\circ}$, da LPI).

Ao final do exame técnico, o INPI irá emitir parecer de deferimento ou indeferimento do pedido, conforme o art. 37 da LPI. Em observância ao duplo grau nos processos administrativos, caberá recurso da decisão que indeferir o pedido de patente. No entanto, da decisão de deferimento não caberá recurso (art. 212, §2 $2^{\circ}$ da LPI).

\footnotetext{
${ }^{26}$ Art. 22. O pedido de patente de invenção terá de se referir a uma única invenção ou a um grupo de invenções inter-relacionadas de maneira a compreenderem um único conceito inventivo. (Lei 9.279/96)

Art. 23. O pedido de patente de modelo de utilidade terá de se referir a um único modelo principal, que poderá incluir uma pluralidade de elementos distintos, adicionais ou variantes construtivas ou configurativas, desde que mantida a unidade técnico-funcional e corporal do objeto. (Lei 9.279/96)

${ }^{27}$ Art. 26 . O pedido de patente poderá ser dividido em dois ou mais, de ofício ou a requerimento do depositante, até o final do exame, desde que o pedido dividido:

I - faça referência específica ao pedido original; e

II - não exceda à matéria revelada constante do pedido original.

Parágrafo único. O requerimento de divisão em desacordo com o disposto neste artigo será arquivado. (Lei 9.279/96)
} 
A proteção, conforme dito anteriormente, é conferida apenas pela cartapatente. Após a decisão de deferimento do pedido de patente, portanto, é necessária a comprovação do pagamento de retribuição ao INPI para que seja expedida a carta-patente (art. 38 da LPI), que trará o prazo de validade da exclusividade.

Por fim, cumpre destacar a possibilidade de instauração de processo administrativo de nulidade da patente por qualquer pessoa que possua legítimo interesse na declaração de nulidade da patente ${ }^{28}$. Desse modo, os requisitos legais podem ser discutidos ainda em sede administrativa, nos termos do art. 50 e seguintes da LPI. No entanto, ainda assim muitas ações judiciais de nulidade de patente são propostas perante o Judiciário, que precisa lidar com matéria complexa tais como o cumprimento dos requisitos legais de patenteabilidade de uma tecnologia inovadora.

\footnotetext{
${ }^{28}$ Art. 51 . O processo de nulidade poderá ser instaurado de ofício ou mediante requerimento de qualquer pessoa com legítimo interesse, no prazo de 6 (seis) meses contados da concessão da patente. (Lei 9.279/96)
} 


\section{Capítulo 3: A morosidade da Administração Pública na concessão de patentes}

\subsection{O backlog de pedidos de patentes no Brasil}

Nas últimas décadas, principalmente em virtude da globalização, muitos países têm experimentado um crescimento considerável na busca por proteção aos direitos de propriedade industrial. O termo backlog é comumente utilizado para expressar o acúmulo de pedidos de patentes pendentes nos escritórios de patente $^{29}$ ao redor do mundo. Nesse sentido, vejamos o seguinte trecho de estudo publicado na Revista da FGV sobre o backlog de patentes no Brasil:

"O exame de uma patente é naturalmente longo e complexo, exigindo alto grau de conhecimento técnico. Como a quantidade de pedidos depositados é superior à quantidade de pedidos decididos, ocorre o acúmulo de pedidos pendentes e, por consequência, um acréscimo temporal cada vez maior para análise de cada pedido." 30

A palavra inglesa "backlog" é definida pelo dicionário online da Oxford como "o acúmulo de trabalho que já deveria ter sido realizado, mas que ainda não foi concluído" 31 . No entanto, a depender do ponto de vista, o acúmulo de trabalho pode significar o total de pedidos pendentes, independentemente de o exame já ter sido iniciado pelo escritório de patente, ou apenas parte deles aqueles que ainda não tiveram seu exame iniciado, por exemplo.

Tendo em vista que o "acúmulo de trabalho" pode ter diversas acepções, para a presente análise, é importante verificar o conceito dado pelo próprio INPI:

\footnotetext{
${ }^{29}$ As instituições que possuem a mesma competência do INPI para decidir os pedidos de patente nos outros países, tais como o USPTO (United States Patent and Trademark Office), o EPO (European Patent Office) e o KIPO (Korean Intellectual Property Office), por exemplo.

30 Júnior, Silvio Sobral Garcez. Moreira, Jane de Jesus da Silveira. "O backlog de patentes no Brasil: o direito à razoável duração do procedimento administrativo", publicado na Revista de Direito da FGV de São Paulo (V. 13 N. 1), Jan-Abr de 2017, p. 178.

${ }^{31}$ Em inglês: "a quantity of work that should have been done already, but has not yet been done". Disponível em: https://www.oxfordlearnersdictionaries.com/definition/english/backlog?q=backlog Acesso em: 08/05/2018.
} 
"Os pedidos de patentes são considerados pendentes de decisão final (backlog) a partir do momento em que são protocolados no INPI. Deste modo, a contagem do número de pedidos pendentes inclui todos os pedidos que ainda não foram resolvidos por qualquer razão. A decisão do pedido decorre por duas razões: por irregularidade administrativa, que pode acontecer a qualquer momento na vida do pedido, ou por exame técnico". ${ }^{32}$

Na definição proposta pelo INPI, portanto, o backlog engloba todos os pedidos de patente pendentes, ou seja, aqueles que ainda não possuem decisão final. É esta acepção que utilizaremos no presente trabalho, a fim de analisar os impactos do cenário do backlog de patentes no Brasil, sob a ótica dos princípios constitucionais que regem a atuação da Administração Pública e os processos administrativos.

O backlog gera um cenário de incerteza e insegurança jurídica, enfraquecendo o sistema patentário, na medida em que impede a concretização de seu objetivo de promoção do desenvolvimento tecnológico e científico do país. Isto ocorre porque a incerteza relativa à proteção patentária traz riscos aos investidores e, consequentemente, desencoraja os investimentos, criando obstáculos à inovação científica e tecnológica.

É certo que diversos fatores contribuem para a demora excessiva no processamento dos pedidos de patente: como a globalização, que contribuiu para o aumento da demanda, o natural aumento do número de pedidos de patente a cada ano, problemas de gestão, a falta de recursos suficientes (não só materiais, mas principalmente a falta de pessoal), e a complexidade das matérias submetidas ao exame do INPI.

Nesse sentido, importa ressaltar que a análise dos requisitos de patenteabilidade de uma invenção requer um esforço técnico grande dos examinadores, que são especializados nas matérias dos pedidos de patente que

\footnotetext{
32 Relatório de Gestão do INPI de 2013. Disponível em: http://www.inpi.gov.br/sobre/arquivos/relatorio_de_gestao_prestacao_de_contas_inpi_2013.pdf Acesso em: 08/05/2018.
} 
analisam. Isto porque o progresso tecnológico implica invenções cada vez mais complexas e acaba levando ao aumento do número de documentos que compõem o estado da técnica ${ }^{33}$, o que torna o procedimento ainda mais complexo.

O INPI, como autarquia federal com expertise na área de propriedade industrial, possui divisões internas a fim de otimizar o fluxo de trabalho de acordo com as especialidades. Por isso, há a Diretoria de Patentes, Programas de Computador e Topografia de Circuitos Integrados, que além de examinar e decidir os pedidos de patente, também realiza o registro dos pedidos de programas de computador (nos termos da Lei ${ }^{\circ}$ 9.609/98 e da Lei $n^{\circ} 9.610 / 98$ ) e dos pedidos de topografias de circuitos integrados (nos termos da Lei $n^{\circ}$ 11.484/2007). Além da DIRPA, que internamente possui divisões especializando ainda mais as atividades dos agentes de acordo com suas áreas de atuação, existe também a Diretoria de Marcas, Desenhos Industriais e Indicações Geográficas.

Conforme o último relatório de atividades do INPI $^{34}$, a DIRPA leva, em média, 10,23 anos para decidir um pedido de patente. É interessante perceber que, caso fosse respeitado pela Administração Pública o prazo para a prática dos atos administrativos previsto no art. 224 da LPI (sessenta dias), um pedido de patente no qual fossem proferidos apenas dois pareceres técnicos, o procedimento administrativo para a concessão da patente levaria no máximo 4 $\operatorname{anos}^{35}$, considerando o prazo de 90 (noventa) dias para o depositante se manifestar sobre o parecer do INPI.

\footnotetext{
${ }^{33}$ Júnior, Silvio Sobral Garcez. Moreira, Jane de Jesus da Silveira. "O backlog de patentes no Brasil: o direito à razoável duração do procedimento administrativo", publicado na Revista de Direito da FGV de São Paulo (V. 13 N. 1), Jan-Abr de 2017, p. 197.

34 Dados constantes do Relatório de Atividades 2017 do INPI. Disponível em: http://www.inpi.gov.br/sobre/estatisticas Acesso em: 05/05/2018.

${ }_{35}$ Considerando que todo o prazo do INPI para proferir decisões (60 dias) e todo o prazo para o manifestante requerer o pedido de exame (36 meses), se manifestar acerca dos pareceres do INPI (90
} 
Quando se analisa o tempo médio de decisão de pedidos de patente por área $^{36}$, o cenário pode se tornar um pouco melhor ou muito pior. Enquanto o exame de patentes de modelo de utilidade leva em média 7,82 anos e de patentes na área de cosméticos e dentifrícios leva em média 7,38 anos, uma invenção na área de telecomunicações leva em média 13,69 anos aguardando a decisão final do pedido de patente. $\mathrm{Na}$ área de fármacos, a média varia de 13,20 anos a 13,63, e na área de petróleo e engenharia química, a média é de 10,26 anos.

É compreensível que o processamento de um pedido de patente de modelo de utilidade tenha uma duração menor do que o de uma patente de invenção, seja qual for a matéria objeto da invenção, tendo em vista que os modelos de utilidade possuem menor grau de atividade inventiva - o que pode tornar a análise um pouco menos complexa.

Ainda assim, a média de duração de aproximadamente 13 anos na área de fármacos, por exemplo, atenta não só contra a eficiência e a duração razoável do processo, como será visto a seguir, mas também prejudica o desenvolvimento científico na área da saúde. Isto porque os investimentos em inovação ficam desestimulados em um cenário no qual a proteção patentária pode vir a ser concedida apenas 13 anos após o depósito do pedido. Considerando que tais invenções por si só levam longos anos para serem criadas, esse cenário de mais de 10 anos aguardando pela concessão da patente após o depósito não é propício para fomentar a inovação.

Além disso, uma demora de aproximadamente 13 anos na área de telecomunicações pode tornar a invenção obsoleta, tendo em vista que se trata de uma área na qual o progresso tecnológico ocorre de forma muito veloz.

dias) e comprovar o pagamento da retribuição para a expedição da carta-patente (60 dias) sejam utilizados, o que nem sempre ocorre.

36 Dados constantes do Relatório de Atividades 2017 do INPI. Disponível em: http://www.inpi.gov.br/sobre/estatisticas Acesso em: 05/05/2018. 
Conforme dados disponíveis no endereço eletrônico da autarquia, no ano de 2017 a DIRPA alcançou o número de 55 decisões técnicas por examinador de patentes, diminuindo o backlog de pedidos de patente em 7,6\%. Nos últimos 10 anos, o backlog vinha aumentando de forma muito rápida, como pode ser observado no gráfico abaixo (figura 1), apresentado em arquivo disponibilizado no endereço eletrônico da autarquia ${ }^{37}$.

\section{Figura 1:}

\section{NÚMERO DE PEDIDOS DE PATENTES DE INVENÇ̃̃O E DE MODELOS DE UTILIDADE}

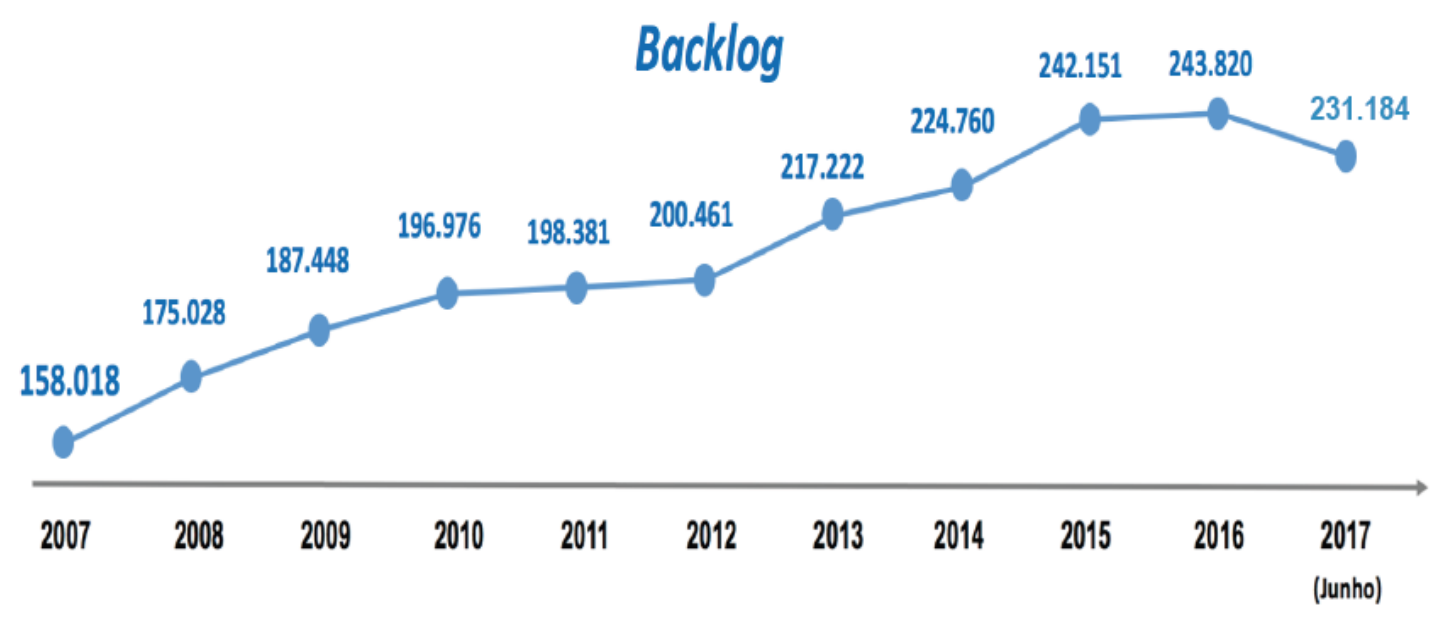

Fonte: INPI/DIREXIAECON.

\section{$\boldsymbol{L} \boldsymbol{P I}=$}

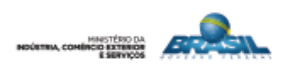

Fonte: site do INPI

Apesar da diminuição do backlog em 2017, em outro gráfico apresentado no mesmo arquivo disponibilizado no endereço eletrônico da autarquia ${ }^{38}$ (figura

\footnotetext{
${ }^{37}$ Gráfico exibido em apresentação do Presidente do INPI em evento da Confederação Nacional da Indústria. Disponível em: http://www.inpi.gov.br/noticias/em-evento-da-cni-inpi-apresenta-medidaspara-reduzir-o-backlog-de-patentes Acesso em: 26/05/2018.

${ }^{38}$ Gráfico exibido em apresentação do Presidente do INPI em evento da Confederação Nacional da Indústria. Disponível em: http://www.inpi.gov.br/noticias/em-evento-da-cni-inpi-apresenta-medidaspara-reduzir-o-backlog-de-patentes Acesso em: 26/05/2018.
} 
2), é possível observar que se o INPI mantiver a produtividade de 55 decisões em exame técnico por examinador por ano, em 2029 o backlog de patentes terá sofrido um aumento de aproximadamente $43 \%$ (de 243.820 pedidos pendentes em 2016 para 349.089 pedidos pendentes em 2029).

Caso essa produtividade aumente em 50\% (83 decisões em exame técnico por examinador por ano), o backlog continuará crescendo, e atingirá o número de 267.748 pedidos pendentes em 2029 , um aumento de aproximadamente $10 \%$.

Não obstante, o dado que mais impressiona é que caso a produtividade dobre, o backlog sofrerá uma diminuição inexpressiva: passará de 243.820, em 2016, para 189.312, em 2029. Ou seja, ainda que a produtividade melhore consideravelmente, alcançando o número de 110 decisões em exame técnico por examinador por ano, o backlog terá sofrido uma diminuição de aproximadamente $22 \%$ apenas, em 13 anos.

\section{Figura 2:}

\section{CENÁRIOS DE BACKLOG}
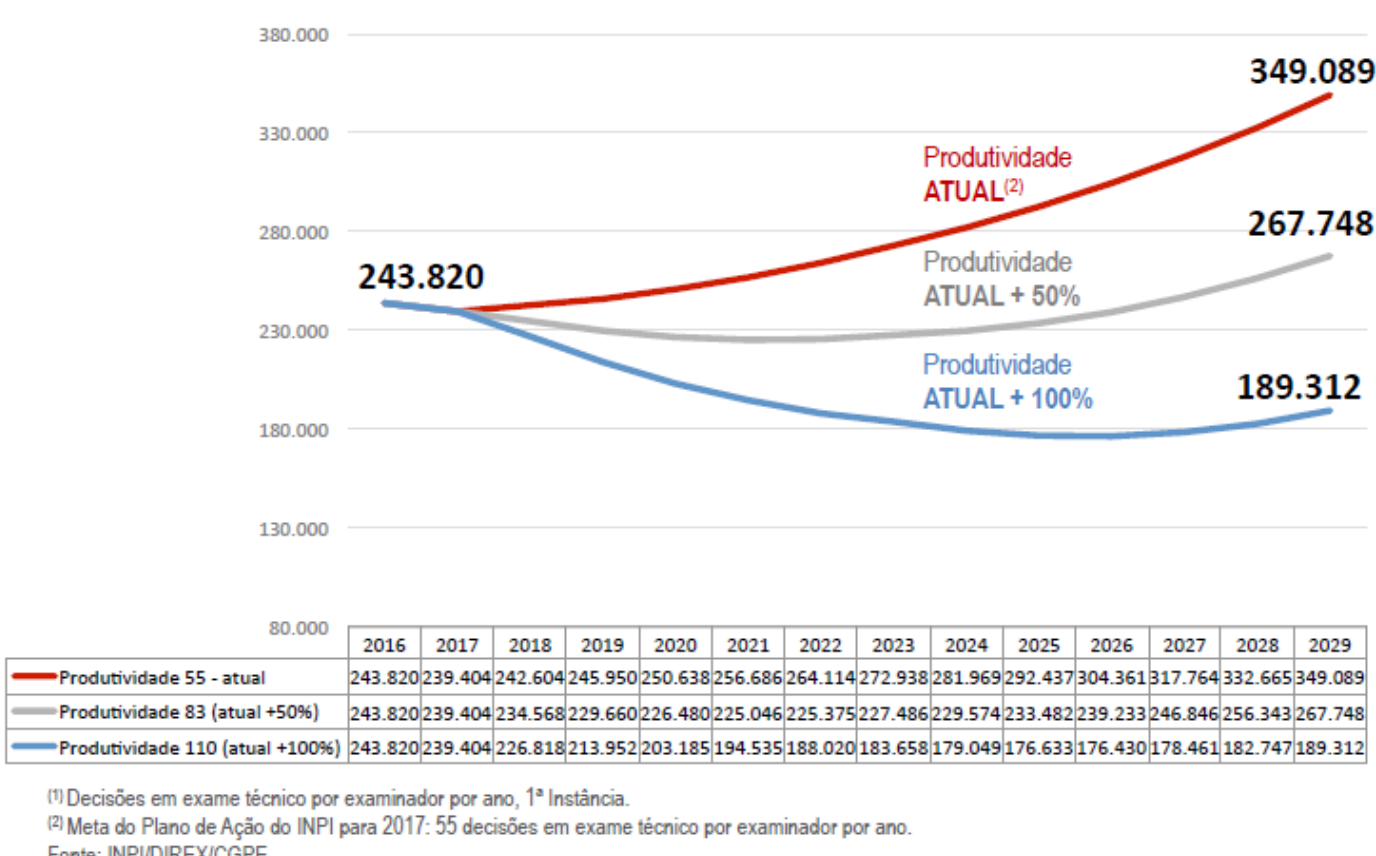

Fonte: INPIJDIREXICGPE. 
O cenário apresentado é preocupante, na medida em que apesar das diversas melhorias que certamente já ocorreram - como, por exemplo, a assinatura de acordos PPH com outros países ${ }^{39}$-, é possível perceber que ainda não há uma perspectiva de que haja uma diminuição considerável no backlog. Consequentemente, o que vemos é que a insegurança jurídica decorrente dessa lentidão permanecerá presente no sistema patentário brasileiro.

Em 2017 houve a proposta de uma solução que aumentará ainda mais a insegurança jurídica: o procedimento simplificado de deferimento de patentes. Os pedidos de patente que atendam aos requisitos estabelecidos serão deferidos no prazo de 90 dias, com exceção dos produtos e processos farmacêuticos, que estão excluídos deste procedimento simplificado.

De acordo com a proposta de norma ${ }^{40}$, que pode ser acessada no endereço eletrônico da autarquia, para que seja admitido o procedimento simplificado do pedido, estes devem atender às seguintes condições: (i) o protocolo do depósito ou do requerimento de entrada na fase nacional do pedido de patente deverá ter sido realizado até a data da publicação da norma; (ii) caso o pedido ainda não tenha sido publicado, a publicação antecipada deve ser requerida até 30 dias da data de publicação da norma; (iii) o exame do pedido deve ser requerido até 30 dias da data de publicação da norma; (iv) o pagamento das retribuições anuais devem estar em dia; (v) não tenha sido iniciado o exame técnico do pedido, com publicação de parecer técnico.

A proposta veio como uma solução milagrosa para o backlog, mas apenas irá mascarar o problema da lentidão. Trará, ainda, ausência de isonomia para os depositantes, uma vez que apenas os pedidos cujo exame ainda não tiver sido

\footnotetext{
${ }^{39}$ O Patent Prosecution Highway (PPH) é um acordo de colaboração entre os escritórios de patente de diferentes países que visa acelerar o exame de patentes ao prever, em resumo, que o depositante do pedido de patente poderá solicitar que o exame do pedido seja priorizado em um país, após ter sido concedido pelo outro.

40 Proposta de norma do Aviso de Consulta Pública $\mathrm{n}^{\circ}$ 02/2017. Disponível em: http://www.inpi.gov.br/menu-servicos/patente/consultas-publicas Acesso em: 09/05/2018.
} 
iniciado serão deferidos em 90 dias. Assim, os depositantes dos pedidos de patente que já tiverem passado por todo o procedimento, adequando seus pedidos às exigências do INPI, mas que estão há anos aguardando uma decisão final, não terão acesso a tal celeridade.

Ademais, é certo que o INPI, ao exercer suas funções, deve atender à demanda de pedidos de patente depositados sem abandonar a qualidade na análise dos pedidos, pelo que deve ser realizado um exame criterioso dos requisitos de patenteabilidade. Caso contrário, o número de litígios envolvendo patentes crescerá, uma vez que existirão motivos para processos administrativos de nulidade ainda no âmbito administrativo e ações de nulidade no Judiciário.

O procedimento simplificado trará justamente isso: um exame precário, que dará ensejo a diversos questionamentos relativos à nulidade dos pedidos de patente. A complexidade de um pedido de patente é incompatível com um exame em 90 dias e a proposta de norma deixa claro que não haverá uma análise criteriosa: da publicação de admissão do pedido no procedimento simplificado será iniciado o prazo de 90 dias para a decisão de deferimento do pedido. $\mathrm{Ou}$ seja, se a decisão será necessariamente de deferimento, é certo que não serão analisados os requisitos de patenteabilidade, pois caso se pretendesse essa análise, haveria a possibilidade de uma decisão de indeferimento.

Portanto, é evidente que o procedimento simplificado não é a maneira mais eficaz de solucionar o problema da morosidade da Administração Pública no reconhecimento do direito à proteção patentária. Antes de qualquer coisa, é preciso que a Administração Pública atue em conformidade com os princípios da eficiência, da duração razoável do processo administrativo e da segurança jurídica, como será visto a seguir. 


\subsection{A violação aos princípios constitucionais e o mandado de segurança como instrumento para acelerar o exame dos pedidos de patente.}

O aumento da fila de pedidos pendentes no INPI é um problema crônico, como visto, e causa enorme prejuízo à sociedade. A lentidão dos processos administrativos para a concessão de patentes preocupa, uma vez que o direito de exclusividade do inventor, previsto constitucionalmente, acaba sendo negativamente afetado, o que desestimula a inovação e o desenvolvimento econômico - elementos de extrema importância para o desenvolvimento de um país.

A ineficiência da Administração Pública no processamento dos pedidos de patente acaba trazendo grande insegurança jurídica, na medida em que os administrados não têm a garantia de obter uma resposta da Administração Pública em tempo razoável acerca dos pedidos de patentes.

Como visto anteriormente, as medidas para a garantia da proteção dos direitos de exclusividade somente podem ser tomadas após a concessão da patente. Isto porque, embora o art. 40, parágrafo único, da LPI, garanta um prazo mínimo de 10 anos de proteção patentária, é necessário que o procedimento administrativo chegue ao fim e a carta-patente seja expedida para que haja uma proteção efetiva aos direitos de exclusividade do titular da patente.

Diante disso, é gerada uma cadeia sem fim que leva ao enfraquecimento do sistema patentário: os depositantes não sabem se terão sua patente concedida e, durante todo o tempo em que o pedido fica pendente de exame, não podem se proteger da contrafação; os investidores não possuem estímulo para apostar seus recursos em inventos que poderão ficar pendentes no INPI por mais de uma década, sem a garantia do direito de exclusividade sobre a sua exploração (que poderá ser negado ao final do processamento do pedido de patente); e os concorrentes precisam lidar com o risco da decisão de pagar ou não os royalties 
pela exploração de um produto ou processo que, após o exame do INPI, poderá ter o direito de exclusividade confirmado ou não pelo INPI.

Assim, não há dúvida de que tal cenário provoca insegurança jurídica não só para os inventores, mas também para os demais agentes afetados pelo sistema patentário: os investidores, os concorrentes e, ainda, os consumidores. Isto porque enquanto o pedido de patente está pendente de análise, não se sabe se a proteção será concedida nem quando essa resposta virá. Essa situação causa instabilidade $\mathrm{e}$, consequentemente, insegurança, pois não existe uma previsibilidade mínima para os administrados em relação ao teor da resposta que obterão da Administração Pública e ao tempo que levará para a obtenção dessa resposta.

Durante esse período de espera de uma decisão final da Administração Pública, os concorrentes podem vir a explorar comercialmente o invento, mas terão de lidar com dois possíveis riscos: o de não pagar royalties pela exploração do produto ou processo ao depositante do pedido de patente e, após o fim do exame no INPI, ser processado por perdas e danos caso a patente seja concedida, conforme previsão do art. 44 da LPI ${ }^{41}$; ou o de pagar royalties ao depositante do pedido de patente sem a certeza do direito de exclusividade, que será confirmado ou não ao fim do exame.

Tal insegurança jurídica desencoraja a concorrência a explorar comercialmente os produtos ou processos objetos de pedidos de patente pendentes, diante da incerteza relativa a necessidade de pagamento de royalties. Ao afetar o mercado, desencorajando a concorrência, é certo que afeta diretamente os consumidores.

\footnotetext{
${ }^{41}$ Art. 44. Ao titular da patente é assegurado o direito de obter indenização pela exploração indevida de seu objeto, inclusive em relação à exploração ocorrida entre a data da publicação do pedido e a da concessão da patente. (Lei 9.279/96)
} 
Não há dúvida de que os inventores sofrem ainda mais com a demasiada lentidão da Administração Pública, posto que possuem o direito constitucional à proteção de seus inventos, mas na prática não tem a garantia de exclusividade enquanto durar o procedimento administrativo no INPI.

Conforme tratado em tópico anterior sobre o princípio da segurança jurídica, há uma legítima expectativa dos administrados em relação àquilo que está previsto no ordenamento jurídico, sendo certo que essa legítima expectativa influencia na tomada de decisões dos indivíduos. Assim, os agentes que se dispõem a investir tempo e recursos na criação de um produto ou processo inovador, considerando que terão direito à exclusividade sobre a exploração do invento pelo prazo previsto em lei, ficam sujeitos à lentidão da Administração Pública para o reconhecimento de seu direito à proteção patentária após anos de pesquisa para o desenvolvimento da inovação.

Tendo em vista que a proteção só será efetiva ao final do exame, com a expedição da carta-patente, o depositante do pedido de patente não pode tomar medidas para proteger seus direitos de exclusividade enquanto estes não forem definitivamente reconhecidos pela Administração Pública.

A incerteza acerca da existência ou não do direito de exclusividade afasta, ainda, os investidores. Nesse sentido, é importante ressaltar que a presença dos investidores é fundamental para dar continuidade às inovações, já que trazem recursos financeiros, contribuindo para a viabilidade das pesquisas.

Portanto, vê-se que a inércia da Administração Pública no processamento dos pedidos de patente possui consequências que afetam diversos agentes do mercado e vão de encontro ao interesse público, pois enfraquece o sistema patentário.

A gestão pública deve buscar os objetivos da lei, tendo sempre em vista o interesse público. Assim, é certo que a duração razoável dos processos administrativos de concessão de patentes não só constitui direito dos 
administrados garantido constitucionalmente, mas também configura interesse público, uma vez que a proteção patentária é essencial para que seja atingido o desenvolvimento tecnológico e econômico do país, tal como preconiza o art. $5^{\circ}$, XXIX, da CRFB/1988.

O princípio da eficiência preconiza, justamente, uma atuação da Administração Pública que busque a produção de resultados satisfatórios. Os serviços públicos, inclusive o exame dos pedidos de patente, devem ser prestados com qualidade e celeridade, assegurando sempre a segurança jurídica e o tratamento isonômico dos usuários. Assim, a Administração Pública deve atuar de forma célere, realizando suas atividades em tempo razoável, mas sempre com qualidade.

No entanto, para atingir resultados satisfatórios em um tempo razoável, é preciso que haja recursos financeiros, humanos e materiais suficientes para atender à demanda da sociedade.

Nesse sentido, cumpre destacar que o número de examinadores da DIRPA é muito baixo quando comparado aos números de backlog do INPI, apresentados no tópico anterior. Atualmente, conforme informações disponíveis no endereço eletrônico da autarquia, há um total de 342 examinadores ativos ${ }^{42}$. Trata-se de um número extremamente baixo para uma autarquia federal, que possui competência para analisar todos os pedidos de patente depositados no país.

Com um número tão alarmante de pedidos pendentes (231.184 pedidos pendentes em 2017), é certo que 342 examinadores ativos não é suficiente para reverter o quadro de backlog do INPI. A resolução do problema do backlog deve ser planejada a longo prazo, incluindo medidas como a contratação de um

\footnotetext{
42 Número de examinadores em março de 2018. Disponível em: http://www.inpi.gov.br/sobre/estatisticas/arquivos/estatisticaspreliminares/ptn_examinadores_2018_aecon_v17042018.pdf Acesso em: 18/05/2018.
} 
número muito maior de examinadores para atender a demanda de um país inteiro e, ainda, de muitas empresas estrangeiras que depositam pedidos de patente no Brasil.

O procedimento simplificado proposto pelo INPI para reduzir o backlog e agilizar o processamento dos pedidos de patente é uma medida que poderá melhorar o problema a curto prazo, mas trará ainda mais insegurança jurídica para esse cenário e atentará, também, contra o princípio da eficiência. Isto porque o princípio da eficiência da Administração Pública não preconiza apenas pela celeridade e produtividade, mas também pela qualidade do serviço prestado.

Conforme visto anteriormente, a introdução da ideia de eficiência como princípio no texto constitucional colocou a produção de resultados como norte da atuação da Administração Pública. Entretanto, isso não significa que os resultados de produtividade tão almejados pelo INPI precisam ser atingidos a qualquer custo.

Por isso, é essencial que as patentes sejam examinadas não apenas de maneira célere, dentro de um prazo razoável, mas também de forma diligente, através de um exame minucioso dos requisitos de patenteabilidade. Destaca-se que a concessão de patentes em 90 dias é incompatível com a complexidade do exame de um pedido de patente. Através do procedimento simplificado, estará sendo deixada de lado a qualidade do exame com a finalidade de atingir tão somente a celeridade e os resultados de produtividade almejados pela Administração Pública.

Isto porque, como visto na proposta de norma do procedimento simplificado, o exame dos pedidos de patente será precário, pois não haverá uma investigação criteriosa acerca do preenchimento dos requisitos legais para a concessão. Dessa forma, diversos pedidos de patente que não cumprem os requisitos legais serão concedidos e seus titulares terão a garantia da exclusividade sem fazer jus a esse direito. 
A medida proposta irá apenas mascarar o problema existente, dando uma "sensação" de agilidade. No entanto, trará ainda mais insegurança jurídica e não resolverá de forma definitiva a questão da lentidão da Administração Pública no processamento de pedidos de patente.

Além disso, a morosidade da Administração Pública no exame dos pedidos de patente tem levado os depositantes dos pedidos a buscar a celeridade na tramitação perante o Judiciário, através da impetração de mandados de segurança individuais com base na omissão administrativa no processamento dos pedidos de patente.

A celeridade dos processos administrativos é essencial para a garantia dos direitos. Não à toa, a Emenda Constitucional $n^{\circ} 45$ acrescentou o inciso LXXVIII ao art. $5^{\circ}$ da Constituição Federal, estabelecendo que "a todos, no âmbito judicial e administrativo, são assegurados a razoável duração do processo e os meios que garantam a celeridade de sua tramitação". O direito à duração razoável do processo no âmbito administrativo tem por base o princípio da eficiência da Administração Pública, buscando impedir a existência de situações de excessiva demora nos processos administrativos, como ocorre no reconhecimento do direito à proteção patentária.

Nesse sentido, a Segunda Turma Especializada do TRF2 entende que " $o$ princípio constitucional da razoável duração dos processos vincula também a Administração Pública, devendo o INPI conciliar o imperativo da impessoalidade com o da eficiência, para reduzir a estocagem de pedidos em exame, segundo a natureza e o grau de complexidade dos registros em espécie"43.

\footnotetext{
${ }^{43}$ TRF2 - Apelação e reexame necessário no 0803242-13.2010.4.02.5101, $2^{\mathrm{a}}$ Turma Especializada, Relatora Des. Federal Nizete Lobato Carmo, publicado em 03/05/2012.
} 
Como mencionado anteriormente, o próprio legislador reconheceu a ineficiência da Administração Pública no processamento dos pedidos de patente ao estabelecer no parágrafo único do art. 40 da LPI o prazo mínimo de 10 anos para a vigência da patente de invenção e de 7 anos para a patente de modelo de utilidade. O dispositivo legal basicamente prevê que, se o INPI demorar mais de 10 anos para conceder uma patente de invenção ou mais de 7 anos para conceder uma patente de modelo de utilidade, o titular deverá ter assegurado o respectivo prazo mínimo de vigência da patente. Assim, vê-se que a própria Lei leva em consideração a morosidade da Administração Pública ao fixar um prazo mínimo de vigência da patente.

Desse modo, a eficiência e a razoável duração do processo constituem fundamentos para a utilização do mandado de segurança como instrumento para buscar o processamento mais rápido dos pedidos de patente. $\mathrm{O}$ ato coator, nesse caso, é a omissão da Administração Pública e o direito líquido e certo é o direito do depositante à razoável duração do processo administrativo, que tem por conteúdo o princípio da eficiência.

Tendo em vista que o INPI é autarquia federal, a Justiça Federal é competente para processar e julgar esses mandados de segurança, nos termos do art. 109, inciso VIII, da CRFB/88. Os mandados de segurança envolvendo a autarquia são julgados pela Justiça Federal da Segunda Região, tendo em vista que a sede do INPI está localizada no Rio de Janeiro.

A jurisprudência do TRF-2 é pacífica no sentido de reconhecer o mandado de segurança como instrumento processual adequado para acelerar os processos administrativos no INPI - não só em relação aos pedidos de patente, objeto do presente trabalho, mas também em relação aos pedidos de registro de marca, cujo processamento também é de competência da autarquia. Vejamos alguns exemplos: 
PROCESSO CIVIL - PROPRIEDADE INDUSTRIAL - REMESSA - MANDADO DE SEGURANÇA. ATO OMISSIVO. INÉRCIA DA ADMINISTRAÇÃO. PRINCÍPIO DA EFICIÊNCIA.

- Remessa em face de sentença que concedeu a segurança pleiteada pela autora, para atacar ato do presidente do INPI, objetivando o imediato processamento de oposição por ela proposta em relação ao pedido de registro de marca n. ${ }^{\circ}$ 906.796.504, de titularidade de terceiros.

- A omissão prolongada da autoridade impetrada implica em abuso de poder, cabendo ao Poder Judiciário, sem configurar invasão na esfera administrativa, suprir tal deficiência, tendo por base o direito à razoável duração do processo e aos meios que garantam a celeridade de sua tramitação, assegurados a todos como direito fundamental, no âmbito judicial e administrativo, conforme o texto do inciso LXVIII, do art. $5^{\circ}$, da Constituição Federal.

- Precedentes jurisprudenciais. Remessa desprovida.

(TRF2 - Remessa ex offício n ${ }^{\circ}$ 0035429-63.2017.4.02.5101, 1 $1^{\text {a }}$ Turma Especializada, Relator: Des. Federal Paulo Espírito Santo, julgado em 14/12/2017)

"REMESSA NECESSÁRIA. MANDADO DE SEGURANÇA. RAZOÁVEL DURAÇÃO DO PRAZO ADMINISTRATIVO. EFICIÊNCIA. PEDIDO DE PATENTE DEPOSITADO EM 22.04.2004, COM ANUÊNCIA PRÉVIA CONCEDIDA EM 27.05.2014, E QUE DESDE ENTÃO AGUARDAVA INÍCIO DO JULGAMENTO DO MÉRITO PELO INPI. FIXADO PRAZO DE 60 DIAS PARA PROFERIMENTO DE CADA ATO ADMINISTRATIVO. SENTENÇA MANTIDA.

I - A hipótese é de remessa necessária de sentença que reconheceu a demora excessiva do INPI no exame de pedido de patente de medicamento anti-inflamatório depositado em 22.04.2004 e determinou que a autarquia prosseguisse no exame e proferisse cada ato administrativo subsequente, até o esgotamento da fase administrativa, no prazo de 60 dias.

II - A anuência prévia foi concedida em 27.05.2014 e desde então o pedido de patente estava aguardando o início do exame do mérito pelo INPI, sem que houvesse qualquer motivo para essa demora.

III - O direito à razoável duração do processo é norma constitucional de eficácia plena prevista no art. $5^{\circ}$, LXXVIII, da CRFB, e, como tal, dispensa regulamentação legal para a produção de seus efeitos. Nada obstante, ao menos no âmbito administrativo federal, a Lei 9.784/99 em seu art. 49 determina que, "[c]oncluída a instrução de processo administrativo, a Administração tem o prazo de até trinta dias para decidir, salvo prorrogação por igual período expressamente motivada".

IV - Sentença que entendeu que o prazo de 30 dias seria inexequível pelo INPI, de modo que, após sopesar as deficiências da autarquia, acertadamente fixou o prazo de 60 dias para o proferimento de cada ato administrativo.

$\mathrm{V}$ - Remessa necessária a que se nega provimento."

(TRF2 - Remessa ex offício n ${ }^{\circ}$ 0093843-88.2016.4.02.5101, 2 $2^{\mathrm{a}}$ Turma Especializada, Relatora: Des. Federal Simone Schreiber, julgado em 31/10/2017) 
DIREITO DA PROPRIEDADE INDUSTRIAL E PROCESSUAL CIVIL. REMESSA NECESSÁRIA DE SENTENÇA QUE, NOS AUTOS DE MANDADO DE SEGURANÇA, DEFERIU A ORDEM NO SENTIDO DE PARA DETERMINAR O DEFERIMENTO DA PI 0012434=6, BEM COMO, APÓS O PAGAMENTO DA RETRIBUIÇÃO ESPECÍFICA PREVISTA NO ARTIGO 38, CAPUT, DA LEI No 9.279-96, QUE SEJA CONCEDIDA A PATENTE REQUERIDA.

I - O presente mandado de segurança foi impetrado com o objetivo de compelir a autoridade coatora a proferir decisão de deferimento do requerimento de patente PI 0012434-6 referente a "composto, processo para a preparação do mesmo, uso de um composto, e, composição farmacêutica".

II - Conforme se depreende dos autos, verifica-se que o requerimento da patente está apto ao deferimento desde 10.12.2013, data em que ocorreu a notificação da anuência prévia pronunciada pela ANVISA na RPI $n^{\circ} 2240$, mas a autarquia federal apenas proferiu a decisão após o deferimento da liminar no presente mandado de segurança, em 29.01.2016, ou seja, decorridos mais de dois anos.

III - Evidente, assim, que a conduta omissiva da autarquia federal violou o direito à razoável duração do processo administrativo assegurada no inciso LXXVIII do artigo $5^{\circ}$ da Constituição da República ("LXXVIII - a todos, no âmbito judicial e administrativo, são assegurados a razoável duração do processo e os meios que garantam a celeridade de sua tramitação"), além do prazo previsto no artigo 49 da Lei

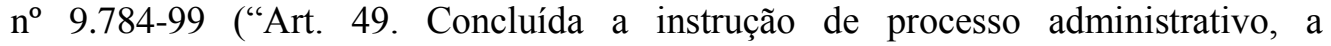
Administração tem o prazo de até trinta dias para decidir, salvo prorrogação por igual período expressamente motivada"), também aplicável aos procedimentos administrativos que tramitam no âmbito do INPI. Acresça-se a isso o dever da Administração emitir decisão a respeito dos requerimentos realizados pelo administrado, também previsto na Lei n ${ }^{\circ}$ 9.784-99 em seu artigo 48: "A Administração tem o dever de explicitamente emitir decisão nos processos administrativos e sobre solicitações ou reclamações, em matéria de sua competência".

IV - Não merece prosperar o requerimento do impetrado no sentido de extinção do mandado de segurança sem apreciação do mérito em razão da publicação do deferimento da patente do ato na RPI $\mathrm{n}^{\circ} 2356$ de 01.03.2016, pois tal fato só ocorreu por força do deferimento da liminar no presente processo, não havendo que falar em perda de objeto da ação, mas sim na necessidade de conferir caráter definitivo à tutela deferida provisoriamente ao impetrante diante da constatação da "liquidez e certeza" do direito invocado, de modo dar efetividade à prestação jurisdicional pleiteada pela parte. Nesse contexto, não se pode olvidar que, nos termos do artigo $\S 3^{\circ}$ do artigo $7^{\circ}$ da Lei n. ${ }^{\circ}$ 12.016-2009, "os efeitos da medida liminar, salvo se revogada ou cassada, persistirão até a prolação da sentença”, razão por que entendeu corretamente o magistrado a quo ao proferir sentença de mérito para, em cognição exauriente da causa, confirmar a tutela liminar e deferir a ordem pleiteada pela impetrante.

V-Remessa necessária desprovida.

(TRF2 - Remessa ex offício $\mathrm{n}^{\mathrm{o}}$ 0001956-23.2016.4.02.5101, $2^{\mathrm{a}}$ Turma Especializada, Relator: Des. Federal André Fontes, julgado em 27/09/2016) 
A morosidade da Administração Pública no processamento de pedidos de patente, pode custar, além da insegurança jurídica, a não garantia de direitos. Isso porque as invenções correm um sério risco de se tornarem obsoletas após mais de 10 anos do depósito - tempo médio atual para o INPI decidir pedidos de patente. Esse risco se agrava para as invenções em setores nos quais as mudanças tecnológicas ocorrem a todo momento, como na área de telecomunicações, em que o INPI tem demorado em média 13 anos para decidir, como visto no tópico anterior.

Há caso de pedido de patente na área de telecomunicações em que o INPI ficou completamente inerte durante 9 anos, desde o requerimento de exame do pedido, sem proferir qualquer parecer a fim de dar início ao exame do pedido. Tal caso chegou ao Judiciário através do mandado de segurança $n^{\circ} 0157858$ 32.2017.4.02.510, cuja sentença reconheceu, mais uma vez, a ineficiência da Administração Pública no exame dos pedidos de patentes:

"Registre-se, contudo, que, apesar do longo tempo decorrido, o INPI ainda não iniciou
o exame dos referidos pedidos de patente, de forma a possibilitar o deferimento ou não
dos mesmos e, conforme o caso, a expedição da correspondente carta-patente, nos
moldes dos artigos 34 a 38 da Lei n. $9.279 / 96$ (que regula direitos e obrigações relativos
à propriedade industrial), o que realmente fere o disposto na Emenda Constitucional n.
45/2004 e nos princípios da razoabilidade e da eficiência administrativa." (Sentença no Mandado de Segurança nº 0157858-32.2017.4.02.5101, SJRJ, Juíza Federal Ana Amélia Antoun Netto, 9 $9^{a}$ Vara Federal do Rio de Janeiro, j. 27/10/2017).

Em um dos casos citados acima (mandado de segurança $n^{\circ}$ 000195623.2016.4.02.5101), a autarquia estava omissa desde a anuência prévia da ANVISA (necessária quando se trata de pedido de patente de produto ou processo farmacêutico ${ }^{44}$ ), há 2 anos, sem proferir decisão de mérito para concluir o procedimento administrativo do pedido de patente, que estava em trâmite há mais de 15 anos.

44 Art. 229-C. A concessão de patentes para produtos e processos farmacêuticos dependerá da prévia anuência da Agência Nacional de Vigilância Sanitária - ANVISA. (Lei 9.279/96) 
A duração de 15 anos de um procedimento administrativo de concessão de patente - principalmente no setor farmacêutico, que envolve questões de saúde pública - além de ser irrazoável, atrasa a entrada do invento em domínio público. Isto porque, conforme visto no capítulo anterior, o titular da patente deve ter assegurada a proteção patentária por no mínimo 10 anos, de acordo com previsão do parágrafo único do art. 40 da LPI. É interessante perceber que caso essa regra não existisse, não restariam nem 5 anos de proteção ao titular da patente no caso mencionado - já que o pedido de patente havia sido depositado há mais de 15 anos e o prazo seria de 20 anos contados da data do depósito, de acordo com o caput do art. 40 da LPI -, o que não cumpriria o objetivo do art. $5^{\circ}$, XXIX, da CRFB/88.

A definição do que seria razoável é incerta, mas é evidente que mais de 10 anos para a decisão final da Administração Pública acerca de um pedido de patente é irrazoável e contrário ao interesse público.

O prazo para a prolação de decisão em processo administrativo está definido na Lei do Processo Administrativo Federal (Lei no 9.784/99), aplicável aos processos administrativos no âmbito do INPI, já que se trata de uma autarquia federal. Nesse sentido, a referida lei estabelece, em seu artigo 49, que "concluída a instrução de processo administrativo, a Administração tem o prazo de até trinta dias para decidir, salvo prorrogação por igual período expressamente motivada".

A LPI, por sua vez, prevê, em seu art. 224, que "não havendo expressa estipulação nesta Lei, o prazo para a prática do ato será de 60 (sessenta) dias".

Em uma análise de alguns dos diversos mandados de segurança impetrados contra a mora do INPI, é possível verificar que há sentenças fixando o prazo de 30 dias, bem como há sentenças fixando o prazo de 60 dias para que a autarquia publique decisão no processo administrativo da patente. Vejamos, a título de exemplo, os julgados abaixo: 
"Diante do exposto, CONCEDO A SEGURANÇA, para determinar que a autoridade impetrada tome as providências necessárias a fim de que, no prazo de $\mathbf{6 0}$ (sessenta) dias, seja publicado o primeiro parecer de mérito dos pedidos de patente PI0415218-2 e PI0415219-0, e, caso formulada alguma exigência, sejam concluídos os exames e proferidas as decisões no prazo de sessenta dias após a resposta da empresa, com a posterior publicação na RPI."

(Sentença no Mandado de Segurança $n^{\circ}$. 0157849-70.2017.4.02.5101, SJRJ, Juiz Federal Marcelo Leonardo Tavares, $31^{\text {a }}$ Vara Federal do Rio de Janeiro, j. 06/09/2017).

"Diante do exposto, CONCEDO A SEGURANÇA, para determinar que a autoridade impetrada tome as providências necessárias a fim de que, no prazo de 60 (sessenta) dias, publique o primeiro parecer de mérito do pedido de patente PI 00307802-7 e, caso formulada alguma exigência, seja concluído o exame e proferida decisão no prazo de sessenta dias após a resposta da empresa, com a posterior publicação na RPI. Uma vez efetuado o pagamento da retribuição correspondente, seja concedida a patente e publicada na RPI em sessenta dias, com a expedição da carta patente."

(Sentença no Mandado de Segurança $\mathrm{n}^{\circ}$. 0097520-92.2017.4.02.5101, SJRJ, Juiz Federal Marcelo Leonardo Tavares, $31^{\text {a }}$ Vara Federal do Rio de Janeiro, j. 26/06/2017).

"Em relação aos demais pedidos formulados pela Impetrante, concedo a segurança, determinando ao Impetrado que tomem as providências necessárias para que, em até 30 (trinta) dias, sejam publicadas, na Revista da Propriedade Industrial (RPI), a decisão de deferimento do pedido de patente BR 1220120231207 e a concessão da aludida patente, bem como seja expedida a respectiva carta patente."

(Sentença no Mandado de Segurança ${ }^{\circ}$. 0002824-64.2017.4.02.5101, SJRJ, Juíza Federal Ana Amélia Antoun Netto, $9^{\text {a }}$ Vara Federal do Rio de Janeiro, j. 22/02/2017).

"De tal modo, deve ser concedida em parte a liminar pleiteada, para determinar à autoridade impetrada que, no prazo de 30 (trinta) dias, decida sobre a concessão do pedido de patente PI0012434-6, fazendo publicar na RPI qualquer decisão que se relacione ao mérito do exame."

(Sentença no Mandado de Segurança $n^{\circ}$. 0001956-23.2016.4.02.5101, SJRJ, Juiz Federal Sergio Bocayuva Tavares de Oliveira Dias, $13^{\text {a }}$ Vara Federal do Rio de Janeiro, j. 13/01/2016).

Ambos os prazos são, certamente, muito mais razoáveis do que a demora usual de anos para o proferimento de decisões pelo INPI. Desse modo, a 
impetração de mandado de segurança contra a omissão da autarquia tornou-se medida comum tomada pelos administrados que precisam se submeter ao procedimento administrativo no âmbito do INPI, pois somente através disso tem sido possível obter uma resposta minimamente rápida da Administração Pública.

No entanto, não é admissível que os depositantes de pedidos de patente sempre dependam da impetração de mandado de segurança para obter uma resposta em tempo razoável. Desse modo, faz-se necessário que sejam tomadas medidas práticas, principalmente a contratação de examinadores, caso se queira efetivamente solucionar a morosidade da Administração Pública na análise dos pedidos de patente.

Nesse sentido, a observância dos princípios constitucionais na atuação da Administração Pública é o ponto de partida para o bom funcionamento do sistema patentário. A proteção patentária é direito dos inventores, constitucionalmente previsto, e só será efetivamente garantido com a observância dos princípios da eficiência, duração razoável do processo administrativo e segurança jurídica.

O fortalecimento do sistema patentário é essencial para o desenvolvimento tecnológico e econômico do país. Mas para que ele seja alcançado, a propriedade industrial precisa ser encarada como uma necessidade elementar pelo Poder Público, pois o bom funcionamento do sistema patentário é parte essencial de qualquer projeto que envolva a promoção do desenvolvimento de um país. 


\section{Conclusão}

A presente análise acerca da morosidade da Administração Pública no procedimento de exame dos pedidos de patente pretende revelar a importância da observância dos princípios constitucionais que regem a atuação da Administração Pública para a efetividade do direito à proteção patentária, bem como a importância do funcionamento adequado do sistema de patentes para o desenvolvimento tecnológico e econômico do país.

Para tal, de início tratei dos princípios da eficiência, da duração razoável do processo administrativo e da segurança jurídica, analisando cada um de forma abstrata a fim de expor seu papel no exercício de todo e qualquer serviço público, inclusive na atividade de exame dos pedidos de patente.

No segundo capítulo, abordei os objetivos e as especificidades do sistema patentário, relatando, ainda, o passo a passo do processo administrativo de concessão de patentes, a fim de esclarecer os principais elementos do objeto do presente trabalho.

Por fim, expus os dados de backlog de pedidos de patente disponibilizados pelo INPI para, então, analisar a morosidade da autarquia no reconhecimento do direito à proteção patentária à luz dos princípios constitucionais da segurança jurídica, da duração razoável do processo administrativo e da eficiência da Administração Pública.

Restou claro que a demora de mais de uma década na análise dos pedidos de patente pela Administração Pública não é razoável e precisa ser combatida através de medidas práticas, tais como a contratação de um número muito maior de servidores capacitados para o exame de pedidos de patente nas mais diversas áreas. 
Tamanha lentidão foge aos limites do que seria razoável, impedindo que o propósito do sistema patentário, tal como estabelecido pela própria Constituição Federal, seja alcançado.

Como amplamente discutido no presente trabalho, a insegurança jurídica afasta os investimentos em inovação e prejudica os diversos agentes do mercado, na medida em que a incerteza acerca do direito de exclusividade desestimula a entrada da concorrência no mercado e impede que os inventores tenham seu direito garantido, bem como que se protejam de eventual contrafação.

Toda essa insegurança jurídica é causada pela ineficiência da Administração Pública no exame dos pedidos de patente, em razão de um procedimento administrativo extremamente lento.

A morosidade da Administração pública causa, então, o enfraquecimento do sistema patentário e contraria os princípios constitucionais que regem a sua atuação. Somente através da observância desses princípios teremos um sistema patentário eficaz, capaz de efetivamente estimular a inovação e contribuir para a promoção do desenvolvimento tecnológico e econômico do país.

No entanto, a observância dos princípios da eficiência, da duração razoável do processo administrativo e da segurança jurídica depende de medidas que devem ser desenvolvidas e realizadas a longo prazo, a fim de promover uma melhora no desempenho da Administração Pública no exame dos pedidos de patente.

Como visto, tornou-se comum a impetração de mandado de segurança pelos depositantes de pedido de patente para acelerar o procedimento administrativo, com fundamento no direito à duração razoável do processo administrativo - diretamente ligado ao princípio da eficiência da Administração Pública. 
Tal prática é legítima e tem auxiliado os depositantes na busca pela garantia de seus direitos, mas é certo que não soluciona o problema da morosidade da Administração Pública, pelo que é necessário buscar soluções no âmbito da própria Administração Pública, preconizando não só pela celeridade do procedimento, mas também pela qualidade do exame.

Portanto, quando pensamos em soluções para o problema da morosidade da Administração Pública devemos ter sempre em mente os princípios da eficiência e da duração razoável do processo administrativo. Isto porque um sistema patentário eficiente será capaz de garantir a segurança jurídica dos administrados, que terão o reconhecimento do direito à proteção patentária em tempo razoável. 


\section{Bibliografia}

BANDEIRA DE MELLO, Celso Antônio. Curso de Direito Administrativo. 33ª Edição. São Paulo: Malheiros, 2017.

BARBOSA, Denis Borges. "Bases Constitucionais da Propriedade Intelectual". Disponível em: 〈http://www.nbb.com.br/pub/propriedade13.pdf> Acesso em: 27/05/2018.

BARBOSA, Denis Borges. Uma Introdução à Propriedade Intelectual. $2^{\mathrm{a}}$ Edição Revista e Atualizada, versão digital disponibilizada segundo os termos da licença Attribution-NonCommercial-NoDerivs 2.0 Generic (CC BYNC- ND 2.0), conforme http://creativecommons.org/licenses/by-ncnd/2.0/. Disponível em: <http://www.nbb.com.br/pub/denis/introducao_pi.pdf> Acesso em: 30/04/ 2018.

BRASIL. Câmara dos Deputados. Emenda Constitucional no 19, de 1998 Exposição de Motivos. Disponível em: <http://www2.camara.leg.br/legin/fed/emecon/1998/emendaconstitucional-194-junho-1998-372816-exposicaodemotivos-148914-pl.html> Acesso em: $28 / 05 / 2018$.

. Lei $\mathrm{n}^{\mathrm{o}}$ 9.784, de 29 de janeiro de 1999. Regula o processo administrativo no âmbito da Administração Pública Federal. Disponível em: <http://www.planalto.gov.br/ccivil_03/Leis/19784.htm> Acesso em: 28/05/2018.

. Lei $\mathrm{n}^{\circ}$ 9.279, de 14 de maio de 1996. Regula direitos e obrigações relativos à propriedade industrial. Disponível em: <http://www.planalto.gov.br/ccivil_03/Leis/19279.htm> Acesso em: 28/05/2018.

. Tribunal Federal Regional da $2^{\mathrm{a}}$ Região (TRF2). Apelação e reexame necessário $\mathrm{n}^{\mathrm{o}}$ 0803242-13.2010.4.02.5101. $2^{\mathrm{a}}$ Turma Especializada. Relatora Des. Federal Nizete Lobato Carmo, publicado em 03/05/2012.

. Tribunal Federal Regional da $2^{\mathrm{a}}$ Região (TRF2). Remessa ex offício $\mathrm{n}^{\mathrm{o}}$ 0035429-63.2017.4.02.5101, $1^{\mathrm{a}}$ Turma Especializada, Relator: Des. Federal Paulo Espírito Santo, julgado em 14/12/2017. 
. Tribunal Federal Regional da $2^{\mathrm{a}}$ Região (TRF2). Remessa ex offício $\mathrm{n}^{\mathrm{o}}$ 0093843-88.2016.4.02.5101, $2^{\mathrm{a}}$ Turma Especializada, Relatora: Des. Federal Simone Schreiber, julgado em 31/10/2017

. Tribunal Federal Regional da $2^{\mathrm{a}}$ Região (TRF2). Remessa ex offício $\mathrm{n}^{\mathrm{o}}$ 0001956-23.2016.4.02.5101, $2^{\mathrm{a}}$ Turma Especializada, Relator: Des. Federal André Fontes, julgado em 27/09/2016

. Tribunal Federal Regional da $2^{\mathrm{a}}$ Região (TRF2). Seção Judiciária do Rio de Janeiro. Sentença no Mandado de Segurança $\mathrm{n}^{\circ}$. 015785832.2017.4.02.5101. 9 ${ }^{a}$ Vara Federal do Rio de Janeiro, Juíza Federal Ana Amélia Antoun Netto, julgado em 27/10/2017.

. Tribunal Federal Regional da $2^{\mathrm{a}}$ Região (TRF2). Seção Judiciária do Rio de Janeiro. Sentença no Mandado de Segurança $n^{\circ}$. 015784970.2017.4.02.5101, $31^{\text {a }}$ Vara Federal do Rio de Janeiro, Juiz Federal Marcelo Leonardo Tavares, julgado em 06/09/2017.

. Tribunal Federal Regional da $2^{\mathrm{a}}$ Região (TRF2). Seção Judiciária do Rio de Janeiro. Sentença no Mandado de Segurança $n^{\circ}$. 000282464.2017.4.02.5101, $9^{\mathrm{a}}$ Vara Federal do Rio de Janeiro, Juíza Federal Ana Amélia Antoun Netto, julgado em 22/02/2017.

. Tribunal Federal Regional da $2^{a}$ Região (TRF2). Seção Judiciária do Rio de Janeiro. Sentença no Mandado de Segurança $\mathrm{n}^{\circ}$. 000195623.2016.4.02.5101, 13 ${ }^{\mathrm{a}}$ Vara Federal do Rio de Janeiro, Juiz Federal Sergio Bocayuva Tavares de Oliveira Dias, julgado em 13/01/2016.

CERQUEIRA, João da Gama. Tratado da Propriedade Industrial, Volume I, Parte I: Da Propriedade Industrial e do Objeto dos Direitos. Rio de Janeiro: Editora Lumen Juris, 2010.

DI PIETRO, Maria Sylvia Zanella. Direito Administrativo. 27a Edição. São Paulo: Atlas, 2014.

IDS - Instituto Dannemann Siemsen de Estudos de Propriedade Intelectual. Comentários à Lei de Propriedade Industrial. Edição Revista e Atualizada, Rio de Janeiro: Renovar, 2005. 
INPI. Instituto Nacional de Propriedade Industrial. Relatório de Atividades 2017. Disponível em: <http://www.inpi.gov.br/sobre/estatisticas> Acesso em: 05/05/2018.

_. Relatório de Gestão de 2013. Disponível em: <http://www.inpi.gov.br/sobre/arquivos/relatorio_de_gestao_prestacao_de_con tas_inpi_2013.pdf> Acesso em: 08/05/2018.

. Gráfico exibido em apresentação do Presidente do INPI em evento da Confederação Nacional da Indústria. Disponível em: $<$ http://www.inpi.gov.br/noticias/em-evento-da-cni-inpi-apresenta-medidaspara-reduzir-o-backlog-de-patentes> Acesso em: 26/05/2018.

- Proposta de norma do Aviso de Consulta Pública no 02/2017. Disponível em: <http://www.inpi.gov.br/menu-servicos/patente/consultaspublicas> Acesso em: 09/05/2018.

- Número de examinadores em março de 2018. Disponível em: <http://www.inpi.gov.br/sobre/estatisticas/arquivos/estatisticaspreliminares/ptn_examinadores_2018_aecon_v17042018.pdf> Acesso em: 18/05/2018.

JÚNIOR, Silvio Sobral Garcez. MOREIRA, Jane de Jesus da Silveira. "O backlog de patentes no Brasil: o direito à razoável duração do procedimento administrativo", publicado na Revista de Direito da FGV de São Paulo (V. 13 N. 1), Jan-Abr de 2017.

OXFORD. Oxford Learner's Dictionary. Disponível em: <https://www.oxfordlearnersdictionaries.com/definition/english/backlog?q=ba cklog> Acesso em: 08/05/2018.

RAMOS, André Luiz Santa Cruz. GUTERRES, Thiago Martins. Lei de Propriedade Industrial Comentada: Lei 9.279, de 14 de maio de 1996. Salvador: Editora JusPodivm, 2016.

SILVA, José Afonso da. Curso de Direito Constitucional Positivo. $37^{\mathrm{a}}$ Edição. São Paulo: Malheiros, 2014. 